\title{
Diversity, distribution, and azaspiracids of Amphidomataceae (Dinophyceae) along the Norwegian coast
}

\author{
Urban Tillmann $^{\mathrm{a}, *}$, Bente Edvardsen ${ }^{\mathrm{b}}$, Bernd Krock ${ }^{\mathrm{a}}$, Kirsty F. Smith ${ }^{\mathrm{c}}$, Ruth F. Paterson ${ }^{\mathrm{d}}$, \\ Daniela Voß \\ a Alfred Wegener Institute, Am Handelshafen 12, D-27570 Bremerhaven, Germany \\ ${ }^{\mathrm{b}}$ University of Oslo, Department of Biosciences, Section for Aquatic Biology and Toxicology, P.O. Box 1066 Blindern, 0316 Oslo, Norway \\ ${ }^{c}$ Cawthron Institute, Privat Bag 2, Nelson 7042, New Zealand \\ ${ }^{\mathrm{d}}$ Scottish Association for Marine Science, Scotland, PA37 1QA, United Kingdom \\ e Institut für Chemie und Biologie des Meeres (ICBM), Carl von Ossietzky Universität Oldenburg, Schleusenstraße 1, D-26382 Wilhelmshaven, Germany
}

A R T I C L E I N F O

\section{Keywords:}

Azadinium

Amphidoma

Azaspiracids

Norway

New strains

New toxins

\begin{abstract}
A B S T R A C T
Azaspiracids (AZA) are a group of lipophilic polyether compounds which have been implicated in shellfish poisoning incidents around Europe. They are produced by a few species of the dinophycean genera Azadinium and Amphidoma (Amphidomataceae). The presence of AZA toxins in Norway is well documented, but knowledge of the distribution and diversity of Azadinium and other Amphidomataceae along the Norwegian coast is rather limited and poorly documented. On a research survey along the Norwegian coast in 2015 from the Skagerrak in the South to Trondheimsfjorden in the North, plankton samples from 67 stations were analysed for the presence of Azadinium and Amphidoma and their respective AZA by on-board live microscopy, real-time PCR assays specific for Amphidomataceae, and liquid chromatography-tandem mass spectrometry (LC-MS/MS).

Microscopy using live samples and positive real-time PCR assays using a general family probe and two species specific probes revealed the presence of Amphidomataceae distributed throughout the sampling area. Overall abundance was low, however, and was in agreement with a lack of detectable AZA in plankton samples. Single cell isolation and morphological and molecular characterisation of established strains revealed the presence of 7 amphidomatacean species (Azadiniun spinosum, Az. poporum, Az. obesum, Az. dalianense, Az. trinitatum, Az. polongum, Amphidoma languida) in the area. Azaspiracids were produced by the known AZA producing species $A z$. spinosum, Az. poporum and Am. languida only. LC-MS/MS analysis further revealed that Norwegian strains produce previously unreported AZA for Norway (AZA-11 by Az. spinosum, AZA-37 by Az. poporum, AZA-38 and AZA-39 by Am. languida), and also four novel compounds (AZA-50, -51 by Az. spinosum, AZA-52, -53 by Am. languida), whose structural properties are described and which now can be included in existing analytical protocols. A maximum likelihood analysis of concatenated rDNA regions (SSU, ITS1-ITS2, partial LSU) showed that the strains of Az. spinosum fell in two well supported clades, where most but not all new Norwegian strains formed the new Ribotype B. Ribotype differentiation was supported by a minor morphological difference with respect to the presence/absence of a rim around the pore plate, and was consistently reflected by different AZA profiles. Strains of Az. spinosum from ribotype A produce AZA-1, -2 and -33, whereas the new strains of ribotype B produce mainly AZA-11 and AZA-51. Significant sequence differences between both Az. spinosum ribotypes underline the need to redesign the currently used qPCR probes in order to detect all AZA producing Az. spinosum.

The results generally underline the conclusion that for the Norwegian coast area it is important that amphidomatacean species are taken into account in future studies and monitoring programs.
\end{abstract}

\section{Introduction}

Norway has one of the longest coastlines in the world and the sea is a key source of income and an important part of the national culture.
Norwegian seafood exports have always been important for the country's economy, and - next to oil and gas - seafood is the most important exported product with a $\$ 6.4$ billion $(7.2 \%$ of total export) in 2016 (source: https://atlas.media.mit.edu/de/resources/about/). In addition

\footnotetext{
* Corresponding author.

E-mail address: urban.tillmann@awi.de (U. Tillmann).
} 
to wild fisheries, a rapidly growing aquaculture industry is gaining an increasing importance. Salmon, rainbow trout, and several marine finfish (cod, halibut) are by far the most important farmed species, but shellfish farming (blue mussels, oysters) is of increasing importance. A major threat to the growing aquaculture and shellfish industries are marine biotoxins produced by harmful algal species, which can cause large fish kills or which accumulate in marine animals creating potential health problems in human seafood consumers.

Regular or sporadic toxic microalgal blooms in Norwegian waters are mainly formed by dinophytes, haptophytes, or dictyochophytes. Among haptophytes, the ichthyotoxic species Prymnesium parvum frequently has caused recurrent fish kills in fjords of the west coast of Norway (Johnsen and Lein, 1989; Larsen et al., 1993), and the vast bloom of Prymnesium polylepis (as Chrysochromulina polylepis) in 1988 was an outstanding and devastating event for marine life all along the Skagerrak and the Norwegian coast (Dundas et al., 1989). Since the late 1990s, massive fish-killing blooms formed by members of the dictyochophyte genus Pseudochattonella recur along the Scandinavian coasts (Edvardsen et al., 2007; Jakobsen et al., 2012). The dinophyte Karenia mikimotoi caused significant blooms and mortality of farmed salmon mainly in the 1970s-1980s (Dahl and Tangen, 1993). Another concern for Norway are species of Dinophysis which are the cause of diarrhetic shellfish poisoning (DSP). In Norwegian blue mussels DSP has been detected annually since 1984 (Underdahl et al., 1985; Naustvoll et al., 2012). Elevated abundance of Dinophysis spp. in Norway severely affect shellfish production, and on the south and west coast of Norway harvesting of mussels due to elevated toxin content can be prevented for several months each year (Aune et al., 1996; Dahl and Johannessen, 2001). In addition, significant shellfish levels of paralytic shellfish poisoning toxins (PSP toxins) produced by species of Alexandrium have been observed since the 1980s in Norway (Tangen, 1983). The yessotoxins, produced by the dinoflagellate Protoceratium reticulatum, have been responsible for numerous closures of Norwegian commercial shellfisheries (Aasen et al., 2005) since their first identification in 1988 (Lee et al., 1988). Its toxicity to humans, however, is presently uncertain (Tubaro et al., 2010).

Driven by the significant economic losses, strategies on tackling and mitigating the threat and problems from harmful algae have been on the agenda in Norway since the 1980s (Dahl and Tangen, 1999). Among other aspects, the regular monitoring of algae and rapid distribution of this information to the aquaculture industry and public has been identified and have led to the establishment of a commendable monitoring system along the whole Norwegian coast (see http://algaeinfo. imr.no).

One of the more recently discovered algal toxins are azaspiracids (AZA), a group of lipophilic polyketides that can accumulate in seafood and upon human consumption can cause severe gastrointestinal health problems (azaspiracid shellfish poisoning; AZP) (Twiner et al., 2014). Azaspiracids were first recognized in the 1990s after an outbreak of human illness in the Netherlands following the consumption of blue mussels originating from Killary Harbour, Ireland (McMahon and Silke, 1996). Since the structural elucidation of the compound (Satake et al., 1998), elevated AZA levels in shellfish above the EU regulatory level ( $0.16 \mathrm{mg} \mathrm{kg}^{-1}$ mussel meat) has been a recurrent and major problem in Ireland (Salas et al., 2011). The planktonic source of the toxins was first identified in 2007 when the small thecate dinoflagellate Azadinium spinosum was described as a new species and as the first primary source of AZA (Tillmann et al., 2009). Since that time, a number of subsequent studies revealed a high biodiversity within the genus Azadinium, with 12 new species isolated and characterized to date (Tillmann and Akselman, 2016; Luo et al., 2017). Moreover, morphological and molecular data for a new species of the genus Amphidoma, Am. languida, revealed a sister group relationship between Azadinium and Amphidoma (Tillmann et al., 2012a). Toxin production is now known for some but not all species in both genera, with AZA detected in strains of $\mathrm{Az}$. spinosum (Tillmann et al., 2009), Az. poporum (Krock et al., 2012), Az. dexteroporum (Rossi et al., 2017), and Am. languida (Krock et al., 2012). Although Ireland seems to be most seriously affected by AZA contamination events, the compounds have been documented over the last decade in shellfish from numerous geographical sites around the globe (James et al., 2002; Taleb et al., 2006; Vale et al., 2008; Álvarez et al., 2010; Yao et al., 2010; Trainer et al., 2013; Massucatto et al., 2014; Turner and Goya, 2015; Smith et al., 2016; Blanco et al., 2017). In recent years, AZA are now known to also be present and problematic in Norway (James et al., 2002). James et al. (2002) detected the first occurrence of AZA-1, -2 and -3 in blue mussels collected in 1998 in Sognefjorden, western Norway. Moreover, AZA were detected in Norwegian brown crabs collected along the north and north-west coast of Norway (Torgersen et al., 2008). Although the majority of samples were below the regulatory limit, levels up to $733 \mu \mathrm{g} \mathrm{kg}{ }^{-1}$ meat were observed, underlining the necessity of surveillance for AZA along the Norwegian coast. This was emphasized in $2002 / 2003$ by the first closures of mussel farming due to the presence of AZA above the regulatory limit in blue mussels, covering the entire south coast of Norway up to the area around Sognefjorden and two locations at the most northern part of the country (Aasen et al., 2006). In 2005, AZA were detected in water samples from southern Norway at Flødevigen by the solid phase adsorption toxin tracking (SPATT) technique, and levels of AZA of $20-50 \mu \mathrm{kg}^{-1}$ were recorded at the same site in blue mussels (Rundberget et al., 2009). Azaspiracid-1 was present in plankton samples collected in June 2007 in the Skagerrak area and at all stations off the Southern Norwegian coast (Krock et al., 2009).

Whereas the presence of AZA toxins in Norway is thus well documented, knowledge of the distribution and diversity of Azadinium and other Amphidomataceae along the Norwegian coast is rather limited and poorly documented. The species Azadinium caudatum (as Amphidoma caudata) was described from the Norwegian Sea (Halldal, 1953), and this species is known to be common and fairly numerous along the Norwegian coast in some years (Throndsen et al., 2007), but based on a single strain investigated so far this is a non-toxigenic species (Tillmann et al., 2014b). One strain of Azadinium isolated in 2010 from the Oslofjorden has been identified as Az. spinosum based on SSU rDNA sequence and morphology viewed in the electron microscope (Ota \& Edvardsen pers. comm.). Although a whole suite of other molecular markers (HSP90, COB, COX, etc.) are available for that strain (Orr et al., 2012), its morphology or AZA production potential has not been reported.

For a sound monitoring system targeting AZA, more detailed information on the species diversity and the toxin profile of local populations of Amphidomataceae is needed. Monitoring and surveillance of the AZP risk potential with the need to unambiguously identify and quantify the source organisms of AZA is challenging and hindered by a number of facts. First, within Amphidomataceae there is a high diversity of very morphologically similar species. Species of Azadinium are generally small, inconspicuous, and thus difficult to detect and identify by regular light microscopy. Moreover, the co-existence of both toxigenic and non-toxigenic species in the same area has been repeatedly documented (Tillmann et al., 2010, 2012b; Kim et al., 2017). Amphidomataceae are thus a good example for the necessity of applying molecular detection methods in monitoring and early warning systems. A general molecular probe detecting all Amphidomataceae is available (Smith et al., 2016). Moreover, species specific molecular probes have been developed for the first three described species, $A z$. spinosum, Az. poporum, and Az. obesum (Toebe et al., 2013), but many new species and strains potentially affecting specificity and cross-reactivity have been found since then and it is likely that the diversity of the group is not yet fully explored. A significant number of described species (mainly of Amphidoma spp.) have not yet been cultured and analysed for their AZA production potential. Establishment of new strains has revealed a wide diversity in AZA profiles at least for some species such as $A z$. poporum (Krock et al., 2014) and Am. languida (Tillmann et al., 2017a) so that today more than 30 AZA analogues of 
dinoflagellate origin are known (Hess et al., 2014). This is in conflict to existing surveillance programs that - according to the official regulations - quantify only AZA-1, -2 and -3 (with the latter compound only known as a shellfish metabolite). An illustrative example for the need and benefit of advanced local studies comes from the Puget Sound, North Pacific, where Az. poporum, among other, non-toxigenic species, was recorded (Kim et al., 2017). Here, the establishment of cultures enabled the detection of a new AZA structural variant (AZA-59) as the sole AZA produced by these local Az. poporum strains and which now allows the refinement of detection methods to specifically monitor the presence and concentration of this compound (Kim et al., 2017).

The aim of the present study is thus to analyse the occurrence, distribution, abundance, diversity, and toxin production potential of species of Amphidomataceae along the Norwegian coast in order to provide baseline information that is needed for developing an adequate local monitoring of AZA and their producing organisms.

\section{Materials \& methods}

\subsection{Field campaign}

\subsubsection{Sampling}

Data were collected from $10^{\text {th }}$ July to $29^{\text {th }}$ July 2015 onboard RV Heincke (HE448) along the Norwegian coastline and within the adjacent Sognefjorden and Trondheimsfjorden. A total of 67 stations were sampled (Fig. 1). At each station CTD profiles were conducted using a Seabird 'sbe911 +' CTD (Sea-Bird Electronics Inc., Seattle, USA) with sampling rosette. The CTD was equipped with a chlorophyll fluorescence sensor (Fluorometer, WET Labs, Philomath, USA). Data acquisition was carried out via CTD-client onboard; post-processing was done with Seasoft V2. Temperature was corrected to ITS-90 (PrestonThomas, 1990). CTD data is available at Pangaea (Zielinski and Rohardt, 2016). Water samples were collected from specific depths during the up-cast of the instrument using Niskin bottles.

\subsubsection{Sample processing}

2.1.2.1. Chlorophyll. Chl- $a$ concentrations were determined by filtering $0.5 \mathrm{~L}-3.5 \mathrm{~L}$ sampled seawater under low vacuum through $0.7 \mu \mathrm{m}$ pore size, glass fiber filters (Whatman GF/F), pre-washed and rinsed with $0.2 \mu \mathrm{m}$ filtered seawater. Filters were frozen immediately onboard at $-80^{\circ} \mathrm{C}$ until laboratory analysis. Pigment extraction was done within 6 months after the cruise in $90 \%$ acetone-water solution with overnight incubation at $4{ }^{\circ} \mathrm{C}$. Extracts were centrifuged for $10 \mathrm{~min}$ at $3020 \times g$ and the fluorescence of the supernatant was determined at $665 \mathrm{~nm}$ using a pre-calibrated TD-700 laboratory fluorometer (Turner Designs, San Jose, USA). Concentrations of Chl- $a\left[\mu \mathrm{g} \mathrm{L}^{-1}\right]$ were calculated according to EPA method 445 (Arar and Collins, 1997).

2.1.2.2. Application of real-time PCR assays. Plankton samples were collected at each station from 3,8 and $15 \mathrm{~m}$ depth with Niskin bottles. Three litres of seawater from each depth was pre-screened through a $20 \mu \mathrm{m}$ mesh-size Nitex sieve, and pre-screened seawater of all three depths was pooled. An amount of 1.5-4 L depending on particle content of the pooled water was filtered under gentle vacuum ( $<200 \mathrm{mbar}$ ) through $3 \mu \mathrm{m}$ pore-size polycarbonate filters (Millipore, Eschborn, Germany). Filters were attached to the inner wall of a $50 \mathrm{~mL}$ plastic centrifuge tube, and repeatedly rinsed with $1 \mathrm{~mL}$ pre-heated $\left(60^{\circ} \mathrm{C}\right)$ DNA lysis buffer (PL 1, Macherey \& Nagel, Düren, Germany). The lysis buffer was subsequently transferred to a $5 \mathrm{~mL}$ cryovial prefilled with $200 \mu \mathrm{L}$ glass beads (acid-washed, $212-300 \mu \mathrm{m}$, SigmaAldrich, St. Louis, USA) and stored at $-20^{\circ} \mathrm{C}$. Later on, DNA was extracted using the Nucleospin Plant II kit (Macherey \& Nagel) according to the manufacturer's instructions.

DNA extracts were first screened using the Amphidomataceae specific real-time PCR assay (Smith et al., 2016). The optimised assays consisted of a $20 \mu \mathrm{L}$ reaction containing $10 \mu \mathrm{L}$ of Platinum SYBR Green qPCR SuperMixUDG (Invitrogen, Waltham, USA), $0.8 \mu \mathrm{g}$ non-acetylated bovine serum albumin (Sigma-Aldrich), $200 \mathrm{nM}$ of forward and reverse primers (Amp240 F and Amp418R), and $10 \mathrm{ng}$ of DNA template. All PCR reactions in this study were set up manually and all included notemplate control reactions. Assays were run in clear 0.2-mL thin-wall
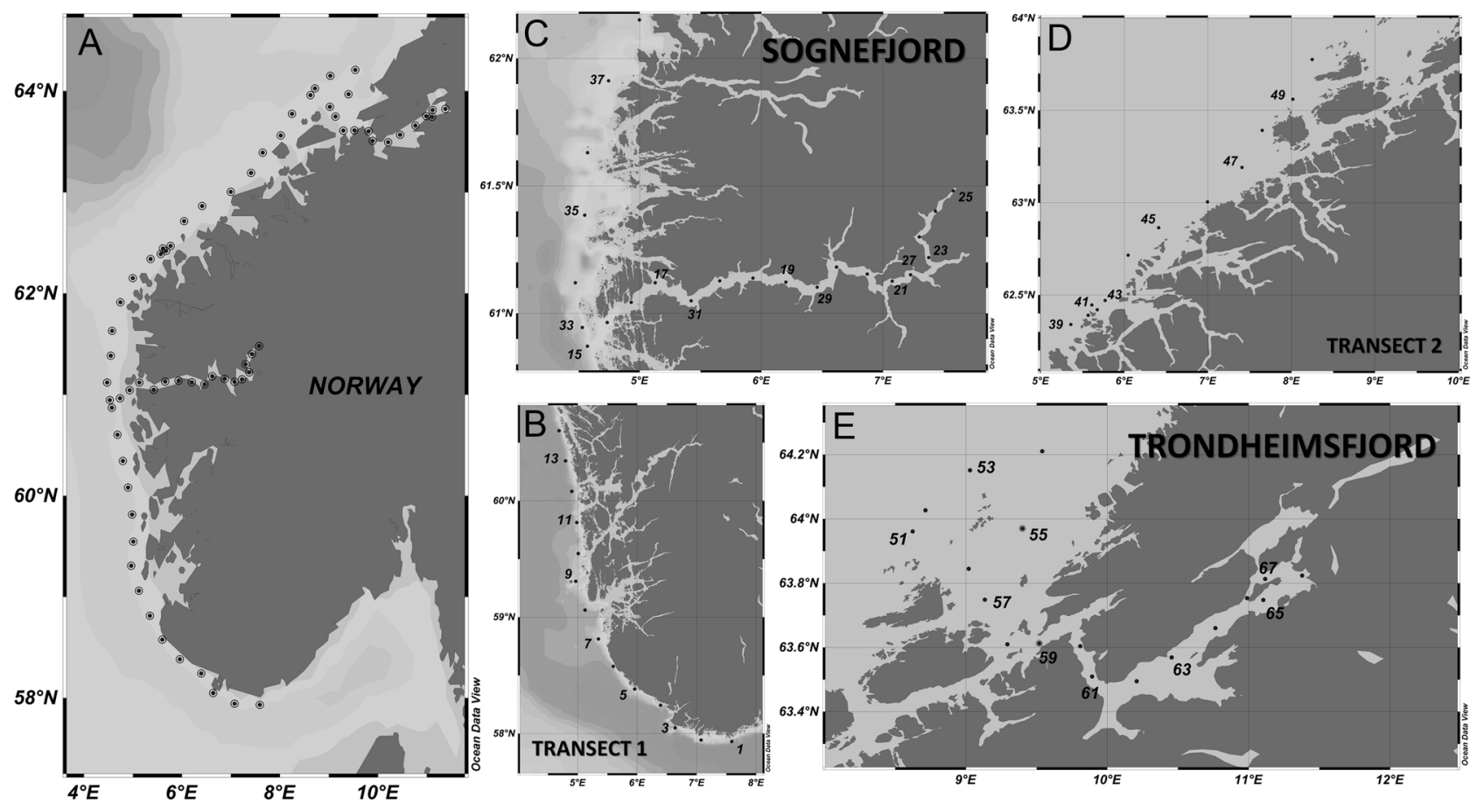

Fig. 1. Study area and location of sampling sites along the Norwegian coast. (A) Overview of Stations. (B) Detailed view of the southern area (transect 1) including station numbers. (C) Detailed view of the Sognefjorden area including station numbers. (D) Detailed view of the nothern area (transect 1) including station numbers. (E) Detailed view of the Trondheimsfjorden area including station numbers. 
PCR tubes (Axygen, Union City, USA). Cycling conditions were as follows: $50^{\circ} \mathrm{C}$ for $2 \mathrm{~min}, 95^{\circ} \mathrm{C}$ for $2 \mathrm{~min}$ and 30 cycles of $95^{\circ} \mathrm{C}$ for $15 \mathrm{~s}$ and $62{ }^{\circ} \mathrm{C}$ for $60 \mathrm{~s}$; followed by a melt curve to confirm amplification specificity. Reactions were deemed positive if an increase in fluorescence was detected before 30 cycles, and the melt temperature of the product was between 82.5 and $84.5^{\circ} \mathrm{C}$. Positive samples were then analysed using Azadinium poporum and Azadinium spinosum real-time PCR assays (Toebe et al., 2013). The optimised assays consisted of a $20 \mu \mathrm{L}$ reaction containing $10 \mu \mathrm{L}$ of Platinum Quantitative PCR SuperMix-UDG (Invitrogen), $0.8 \mu \mathrm{g}$ non-acetylated bovine serum albumin (Sigma-Aldrich), $900 \mathrm{nM}$ of forward and reverse primers (Apop62F / Apop148R and Asp48F / Asp120R respectively), and $200 \mathrm{nM}$ or fluorescent probe (Apop112 and Aspin77T respectively), and $10 \mathrm{ng}$ of DNA template. Cycling conditions were as follows: $50^{\circ} \mathrm{C}$ for $2 \mathrm{~min}, 95^{\circ} \mathrm{C}$ for $2 \mathrm{~min}$ and 40 cycles of $95^{\circ} \mathrm{C}$ for $15 \mathrm{~s}$ and $59^{\circ} \mathrm{C}$ for $60 \mathrm{~s}$. Reactions were deemed positive if an increase in fluorescence was detected before 40 cycles.

2.1.2.3. AZA. For AZA analysis field plankton samples were prepared and filtered as described in 2.1.2.2. Filters were placed with their back to the inner wall of a $50 \mathrm{~mL}$ centrifuge tube (Sarstedt, Nümbrecht, Germany) each and were repeatedly rinsed with $500-1000 \mu \mathrm{L}$ methanol until complete decolouration of the filters. The methanolic extracts were transferred to a spin-filter $(0.45 \mu \mathrm{m}$ pore-size, Millipore Ultrafree, Millipore) and centrifuged for $30 \mathrm{~s}$ at $800 \mathrm{x} g$, followed by transfer to autosampler vials and immediate on-board measurements. Mass spectral experiments were performed to survey for a wide array of AZA with an analytical system consisting of an AB-SCIEX-4000 Q Trap, triple quadrupole mass spectrometer (AB-SCIEX, Darmstadt, Germany) equipped with a TurboSpray interface coupled to an Agilent model 1100 LC (Agilent, Waldbronn, Germany). The liquid chromatography (LC) equipment included a solvent reservoir, in-line degasser (G1379 A), binary pump (G1311 A), refrigerated autosampler (G1329 A/G1330B), and temperature-controlled column oven (G1316 A). Separation of AZA ( $5 \mu \mathrm{L}$ sample injection volume) was performed by reverse-phase chromatography on a C8 phase. The analytical column $(50 \times 2 \mathrm{~mm})$ was packed with $3 \mu \mathrm{m}$ Hypersil BDS $120 \AA$ (Phenomenex, Aschaffenburg, Germany) and maintained at $20^{\circ} \mathrm{C}$. The flow rate was $0.2 \mathrm{~mL} \mathrm{~min}^{-1}$, and gradient elution was performed with two eluents, where eluent A was water and B was acetonitrile/water $(95: 5 \mathrm{v} / \mathrm{v})$, both containing $2.0 \mathrm{mM}$ ammonium formate and $50 \mathrm{mM}$ formic acid. Initial conditions were $8 \mathrm{~min}$ column equilibration with $30 \% \mathrm{~B}$, followed by a linear gradient to $100 \%$ B in $8 \mathrm{~min}$ and isocratic elution until $18 \mathrm{~min}$ with $100 \% \mathrm{~B}$ then returning to initial conditions until $21 \mathrm{~min}$ (total run time: $29 \mathrm{~min}$ ). Azaspiracid profiles were determined in one period (0-18 min) with curtain gas: 10 psi, CAD: medium, ion spray voltage: $5500 \mathrm{~V}$, temperature: ambient, nebulizer gas: $10 \mathrm{psi}$, auxiliary gas: off, interface heater: on, declustering potential: $100 \mathrm{~V}$, entrance potential: $10 \mathrm{~V}$, exit potential: $30 \mathrm{~V}$. Single-reaction-monitoring experiments were carried out in positive ion mode by selecting the transitions shown in Table 1.

\subsubsection{On board microscopy}

Bottle samples ( $8 \mathrm{~m}$ depth) were used for on board microscopical observation and documentation of live cells of Amphidomataceae. Oneliter sample was pre-screened ( $20 \mu \mathrm{m}$ Nitex mesh), gently concentrated by gravity filtration using a $3-\mu \mathrm{m}$ polycarbonate filter $(47 \mathrm{~mm}$ diameter, Whatman), and examined using an inverted microscope (Axiovert $200 \mathrm{M}$, Zeiss, Göttingen, Germany). Cells of Azadinium and/or Amphidoma (generally rare in the samples) were pre-identified at high magnification (640X) based on general cell size and shape, on the presence of a theca, and on the presence of a distinctly pointed apex. Cells of interest were photographed with a digital camera (Axiocam MRc5, Zeiss).

\subsubsection{Onboard isolation and culture}

Pre-identified cells of Amphidomataceae detected during the
Table 1

Mass transitions $m / z(\mathrm{Q} 1>\mathrm{Q} 3$ mass $)$ and their respective AZA.

\begin{tabular}{|c|c|c|}
\hline Mass transition & Toxin & $\begin{array}{l}\text { Collision energy (CE) } \\
\text { [V] }\end{array}$ \\
\hline $6>698$ & AZA-33 & 40 \\
\hline $96>778$ & AZA-33 phosphate & 40 \\
\hline $816>798$ & AZA-39 & 40 \\
\hline $816>348$ & AZA-39 & 70 \\
\hline $828>658$ & AZA-3 & 70 \\
\hline $828>810$ & AZA-3, AZA-43 & 40 \\
\hline $830>812$ & AZA-38, AZA-52, AZA-53 & 40 \\
\hline $830>348$ & AZA-38, AZA-52, AZA-53 & 70 \\
\hline $842>672$ & AZA-1 & 70 \\
\hline $842>824$ & AZA-1, AZA-40, AZA-50 & 40 \\
\hline $842>348$ & AZA-40 & 70 \\
\hline $844>826$ & AZA-4, AZA-5 & 40 \\
\hline $846>828$ & AZA-37 & 40 \\
\hline $846>348$ & AZA-37 & 70 \\
\hline $854>836$ & AZA-41 & 40 \\
\hline $854>670$ & AZA-41 & 70 \\
\hline $854>360$ & AZA-41 & 70 \\
\hline $856>672$ & AZA-2 & 70 \\
\hline $856>838$ & AZA-2 & 40 \\
\hline $858>840$ & $\begin{array}{l}\text { AZA-7, AZA-8, AZA-9, AZA-10, AZA-36, } \\
\text { AZA-51 }\end{array}$ & 40 \\
\hline $858>348$ & AZA-36, AZA-51 & 70 \\
\hline $860>842$ & AZA-59 & 40 \\
\hline $868>362$ & Undescribed & 70 \\
\hline $870>852$ & Me-AZA-2, AZA-42 & 40 \\
\hline $870>360$ & AZA-42 & 40 \\
\hline $872>854$ & AZA-11, AZA-12 & 40 \\
\hline $896>878$ & AZA-39 phosphate & 40 \\
\hline $910>892$ & AZA-38 phosphate & 40 \\
\hline $922>904$ & $\begin{array}{l}\text { AZA-1 phosphate, AZA- } 40 \text { phosphate, } \\
\text { AZA- } 50 \text { phosphate }\end{array}$ & 40 \\
\hline $926>908$ & AZA-37 phosphate & 40 \\
\hline $936>918$ & AZA-2 phosphate & 40 \\
\hline $938>920$ & AZA-36 phosphate, AZA-51 phosphate & 40 \\
\hline $952>938$ & AZA-11 phosphate & 40 \\
\hline
\end{tabular}

onboard live sample observations were isolated by micro-capillary into wells of 96-well plates filled with $0.2 \mathrm{~mL}$ filtered seawater. By the transfer technique, the inclusion of non-target cells was unavoidable. Therefore, each primary well of isolation was partitioned as $10 \mu \mathrm{L}$ quantities distributed into 20 new wells pre-filled with $0.2 \mathrm{~mL}$ filtered seawater. Plates were incubated at $10^{\circ} \mathrm{C}$ under a photon flux density of approx. $50 \mu \mathrm{mol} \mathrm{m}^{-2} \mathrm{~s}^{-1}$ on a $16: 8 \mathrm{~h}$ light:dark photocycle in a controlled environment growth chamber (Model MIR 252, Sanyo Biomedical, Wood Dale, USA).

\subsection{Characterisation of Amphidomataceae strains}

\subsubsection{Culture growth, sampling and extraction}

After 4 weeks of growth, primary isolation plates from the cruise were inspected in the laboratory using a stereomicroscope (SZH-ILLD, Olympus, Hamburg, Germany) for the presence of Azadinium-like cells as inferred from the typical size, shape, and swimming behavior. From each positively identified well, a clonal strain was established by isolation of single cells by micro-capillary and established cultures were thus clonal but not axenic. The clonal cultures were maintained in $70 \mathrm{~mL}$ plastic culture flasks at $15^{\circ} \mathrm{C}$ in a natural seawater medium prepared with sterile-filtered $(0.2 \mu \mathrm{m}$ VacuCap filters, Pall Life Sciences, Dreieich, Germany) Antarctic seawater (salinity: $34 \mathrm{psu}, \mathrm{pH}$ adjusted to 8.0) and enriched with 1/10 strength K-medium (Keller et al., 1987; slightly modified by omitting addition of ammonium ions).

For toxin analysis, strains were grown at $15{ }^{\circ} \mathrm{C}$ under a photon flux density of $50 \mu \mathrm{mol} \mathrm{m}^{-2} \mathrm{~s}^{-1}$ on a 16:8 h light:dark photocycle. For each harvest, cell density was determined by settling Lugol's fixed samples and counting $>800$ cells under an inverted microscope. Densely growing strains (ranging from 0.5 to $5 \times 10^{4}$ cells $\mathrm{mL}^{-1}$ ) were harvested 
by centrifugation (5810R, Eppendorf, Hamburg, Germany) at $3220 \mathrm{xg}$ for $10 \mathrm{~min}$ of $50 \mathrm{~mL}$ subsamples. The cell pellet was resuspended, transferred to a microtube, centrifuged again (Eppendorf 5415, 16,000 $\mathrm{x} g, 5 \mathrm{~min})$, and stored frozen $\left(-20^{\circ} \mathrm{C}\right)$ until use. For a number of selected strains, growth and harvest procedures were repeated several times to yield a high biomass to increase sensitivity of the toxin detection method. The total number of cells harvested for these strains is listed in Suppl. Tab. S1-S4.

Several cell harvests of each strain were combined in $100 \mu \mathrm{L}$ acetone. The extraction of cell pellets was repeated four times with $100 \mu \mathrm{L}$ each and combined cell suspensions were vortexed every $10 \mathrm{~min}$ during one hour at room temperature. Homogenates were centrifuged (Eppendorf $5810 \mathrm{R}$ ) at $15^{\circ} \mathrm{C}$ and $3220 \times g$ for $15 \mathrm{~min}$. Filtrates were then adjusted with acetone to a final volume of $0.5 \mathrm{~mL}$. The extracts were transferred to a $0.45 \mu \mathrm{m}$ pore-size spin-filter (Millipore Ultrafree, Millipore, Burlington, USA) and centrifuged (Eppendorf 5415R) at 800 $\mathrm{x} g$ for $30 \mathrm{~s}$, with the resulting filtrate transferred into an LC autosampler vial for LC-MS/MS analysis.

For DNA extraction, each strain was grown in $65 \mathrm{~mL}$ plastic culture flasks under the standard culture conditions described above. Fifty $\mathrm{mL}$ of healthy and growing culture (based on stereomicroscopic inspection of the live culture) were harvested by centrifugation (Eppendorf 5810R; $3220 \mathrm{x} g, 10 \mathrm{~min})$. Each pellet was transferred to a microtube, again centrifuged (Eppendorf 5415R, 16,000 x $\mathrm{g}, 5 \mathrm{~min}$ ), and stored frozen at $-80^{\circ} \mathrm{C}$ until DNA extraction.

\subsubsection{Microscopy}

\section{Light microscopy (LM)}

Observation of living or fixed cells was carried out with a stereomicroscope (Olympus SZH-ILLD, Olympus) and an inverted microscope (Axiovert $200 \mathrm{M}$, Zeiss). Observation and documentation of live cells at high magnification $(1,000 x)$ was performed using a Zeiss Axioskop 2 (Zeiss) and by recording videos using a digital camera (Gryphax, Jenoptik, Jena, Germany) at full-HD resolution. Single frame micrographs were extracted using Corel Video Studio software (Version X8 pro). Photographs of formaldehyde-fixed cells (1\% final concentration) were taken with a digital camera (Axiocam MRc5, Zeiss). Cell length and width were measured at 1,000x microscopic magnification using Zeiss Axiovision software (Zeiss) and freshly fixed cells (formaldehyde, $1 \%$ final concentration) of strains growing at $15^{\circ} \mathrm{C}$.

Scanning electron microscopy (SEM)

For SEM, cells were collected by centrifugation (Eppendorf 5810R, $3220 \mathrm{xg}, 10 \mathrm{~min}$.) of $15 \mathrm{~mL}$ of culture. The supernatant was removed and the cell pellet re-suspended in $60 \%$ ethanol in a $2 \mathrm{~mL}$ microtube for $1 \mathrm{~h}$ at $4{ }^{\circ} \mathrm{C}$ to strip off the outer cell membrane. Subsequently, cells were pelleted by centrifugation ( $5 \mathrm{~min}, 16,000 \mathrm{x}$, Eppendorf 5415R) and resuspended in a 60:40 mixture of deionized water and seawater for $30 \mathrm{~min}$ at $4{ }^{\circ} \mathrm{C}$. After centrifugation and removal of the diluted seawater supernatant, cells were fixed with formaldehyde ( $2 \%$ final concentration in a 60:40 mixture of deionized water and seawater) and stored at $4{ }^{\circ} \mathrm{C}$ for $3 \mathrm{~h}$. Cells were then collected on polycarbonate filters (Millipore, $25 \mathrm{~mm} \emptyset, 3 \mathrm{~mm}$ pore-size) in a filter funnel where all subsequent washing and dehydration steps were carried out. A total of eight washings ( $2 \mathrm{~mL}$ deionized water each) were followed by a dehydration series in ethanol (30, 50, 70, 80, 95, 100\%; 10 min each). Filters were dehydrated with hexamethyldisilazane (HMDS), first in 1:1 HMDS:EtOH followed by two times $100 \%$ HMDS, and then stored under gentle vacuum in a desiccator. Finally, filters were mounted on stubs, sputtercoated (SC500, Emscope, Ashford, UK) with gold-palladium and viewed under a scanning electron microscope (Quanta FEG 200, FEI, Eindhoven, Netherlands). Some SEM micrographs were presented on a black background using Adobe Photoshop 6.0 (Adobe Systems, San Jose, USA).

\subsubsection{Molecular phylogeny \\ PCR amplification and DNA sequencing}

DNA was extracted from the pellet of $50 \mathrm{~mL}$ cultures of 30 algal strains using DNeasy Plant Mini Kit (Qiagen, Hilden, Germany) according to the manufacturer's protocol. The ribosomal DNA regions SSU, partial LSU and ITS1-5.88S-ITS2 were amplified by PCR in a Mastercycler Gradient thermocycler (Eppendorf) using the primers shown in Supplementary Table S5. The $25 \mu$ PCR reaction contained $12.5 \mu \mathrm{l}$ GoTaqGreen master mix (Promega, Madison, USA), $1.5 \mu \mathrm{l}$ of 5 $\mu \mathrm{M}$ forward and reverse primers, $1 \mu \mathrm{L}$ template, and $8.5 \mu \mathrm{l}$ PCR $\mathrm{H}_{2} \mathrm{O}$ (Eppendorf). The PCR program was as follows: initial denaturation at $94^{\circ} \mathrm{C} 3 \mathrm{~min}$, followed by 35 cycles with denaturation at $94^{\circ} \mathrm{C}$ for $45 \mathrm{~s}$, annealing at 50 (SSU), 52 (LSU) or 60 (ITS) ${ }^{\circ} \mathrm{C}$ for $45 \mathrm{~s}$, and extension at $72{ }^{\circ} \mathrm{C}$ for $2 \mathrm{~min}$ (SSU and ITS) or $1 \mathrm{~min}$ (LSU). After the cycles, extension was completed at $72{ }^{\circ} \mathrm{C}$ for $5 \mathrm{~min}$. The PCR products were loaded onto a $0.8 \%$ agarose gel in TAE buffer, and checked for purity and correct fragment length. The PCR fragments were purified (USB ExoSAP-IT, Thermo Fisher, Massachusetts, USA) and bi-directionally Sanger sequenced at the GATC Biotech sequencing service (Lightrun, Ebersberg, Germany).

Phylogenetic analyses

DNA sequences in both directions were trimmed, pair-wise aligned, and the assembled consensus sequence manually edited in Geneious v. 8.1.6. The DNA sequences of the three rDNA regions (SSU, ITS1-ITS2, partial LSU) of each strain (when available) were then assembled or concatenated into one continuous consensus sequence. Reference sequences from 31 strains of Amphidomataceae and two outgroup dinoflagellate sequences (Suppl. Tab. S6) were downloaded from the NCBI Genbank, concatenated and aligned together with own sequences > 1000 bp by MAFFT E-INS-i (version 7, online, Katoh et al., 2017). Shorter sequences were then added to the alignment by mafft -add (version 7, online). The alignment was truncated at $3611 \mathrm{bp}$.

Phylogenetic analyses were performed in Geneious v. 8.1.6. Maximum likelihood was performed by PhyML (Guindon et al., 2010) using the substitution model General Time Reversible (GRT), where invariable sites and gamma distribution were estimated in the four categories. Tree searches were done with NNI from a default fast starting tree. Bootstrap confidence levels were estimated from 100 replicates. Sequences were submitted to EBI and have the accession numbers as shown in Supplementary Table S7.

\subsubsection{Chemical analysis of azaspiracids}

Extracts of the strains were screened for known AZA in the SRM mode as described above (2.1.2.3).

Precursor ion experiments

Precursors of the characteristic AZA fragments $m / z 348, m / z 360$ and $m / z 362$ were scanned in the positive ion mode from $m / z 400$ to 900 under the following conditions: curtain gas: 10 psi, CAD: medium, ion spray voltage: $5500 \mathrm{~V}$, temperature: ambient, nebulizer gas: $10 \mathrm{psi}$, auxiliary gas: off, interface heater: on, declustering potential: $100 \mathrm{~V}$, entrance potential: $10 \mathrm{~V}$, collision energy: $70 \mathrm{~V}$, exit potential: $12 \mathrm{~V}$.

Product ion spectra

Product ion spectra of the $m / z$ values 830,842 and 858 were recorded in the Enhanced Product Ion (EPI) mode in the mass range from $\mathrm{m} / \mathrm{z} 150$ to 930 . Positive ionization and unit resolution mode were used. The following parameters were applied: curtain gas: 10 psi, CAD: medium, ion spray voltage: $5500 \mathrm{~V}$, temperature: ambient, nebulizer gas: $10 \mathrm{psi}$, auxiliary gas: off, interface heater: on, declustering potential: $100 \mathrm{~V}$, collision energy spread: $0,10 \mathrm{~V}$, collision energy: $70 \mathrm{~V}$.

\section{Results}

\subsection{Field data}

\subsubsection{Temperature, salinity, and chlorophyll}

The Norwegian coast showed a stratified water column with higher temperature and lower salinity values in the upper water column (Fig. 2A-B). Within the upper $50 \mathrm{~m}$ temperature ranged from ca. $7^{\circ} \mathrm{C}$ in 

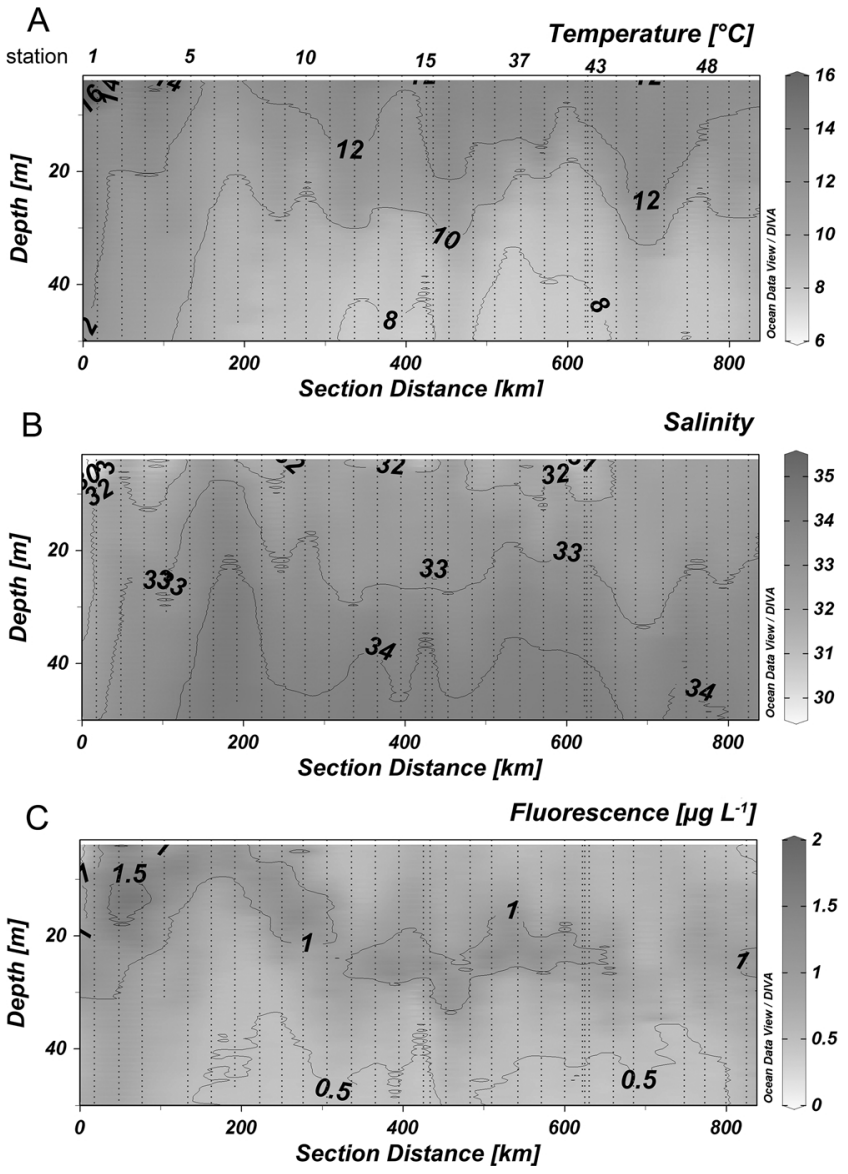

Fig. 2. CTD depth profile $(0-50 \mathrm{~m})$ of (A) temperature, (B) salinity, and (C) chlorophyll fluorescence along the coastal stations from station 1 (left side) to station 50 (right). For the location of stations see Fig. 1.

the deep to $16^{\circ} \mathrm{C}$ in the surface layers (Fig. 2A). Salinities varied in surface waters from below 30 in the Skagerrak region, not exceeding ca. 33 along the whole transect. Higher saline seawater (up to 35) was found below $30 \mathrm{~m}$ (Fig. 2B). The chl- $a$ fluorescence was highest in the Skagerrak region with a deep chlorophyll maximum (DCM) at approx. $15 \mathrm{~m}$. Going further north the DCM subsided, fluctuating around $25 \mathrm{~m}$ depths (Fig. 2C).

The two large fjords sampled, i.e. Sognefjorden and Trondheimsfjorden, exhibited a stratified water column with a lowsaline upper layer and high saline seawater below. In both fjords there was a salinity gradient ranging from $\sim 1$ in the inner fjord section to $\sim 30$ in the outer fjord with chlorophyll maxima found in the end section of the Sognefjorden and at the inlet of the Trondheimsfjorden (results not shown).

\subsubsection{On board microscopy records of Amphidomataceae}

On board microscopy using live samples revealed the presence of Amphidomataceae throughout the sampling area (Fig. 3). Classification was based on size, shape, and the presence of a distinctly pointed apex. No attempt was made to identify cells to species level. Generally low levels of cell encounter in concentrated bottle samples indicated a generally low abundance of Amphidomataceae with a rough estimate of cell densities in the order of $1-100$ cells $\mathrm{L}^{-1}$. Time constraints did not allow detailed light microscopy at all stations and the time and effort available to check samples also varied, so a lack of record in Fig. 3 does not mean absence of Amphidomataceae at this station, and the number of cells depicted in Fig. 3 are not reflective of quantitative abundance.

\subsubsection{Results of the application of real-time PCR assays}

All DNA extracts analysed using real-time PCR were positive for Amphidomataceae (Fig. 4). Both Azadinium poporum and Az. spinosum were extremely common, detected in almost all DNA extractions. At a few locations, the Amphidomataceae assay was positive, while the $A z$. poporum and $A z$. spinosum assays were both negative, indicating the presence of other Amphidomataceae species in the water column.

\subsubsection{AZA in field samples}

None of the known AZA listed in Table 1 were detected in the $3-20 \mu \mathrm{m}$ size fractions of sea water samples. The limits of detection (signal-to-noise ratio $=3$ ) of these measurements ranged between 46 and $100 \mathrm{pg} \mathrm{L}^{-1}$ seawater depending on the water volume filtered and filter extraction volume.

\subsection{Amphidomataceae, new strains}

On board single cell isolation yielded 33 clonal strains (Table 2) which were confirmed as species of Azadinium and Amphidoma, including Am. languida (13 strains), Az. dalianense (5 strains), Az. poporum (3 strains), Az. obesum (1 strain), Az. trinitatum (1 strain), Az. polongum (1 strain), and $A z$. spinosum (9 strains). Identification of all strains was based on morphology as examined by LM (all strains) and SEM (most strains) and was confirmed for most strains by rRNA gene sequence comparison. Origin of strains covered the whole Norwegian coast (Table 2).

\subsubsection{Morphological characterisation of strains/species}

All strains displayed a similar and conspicuous swimming behaviour consisting of a slow movement interrupted by short "jumps" in various directions. Moreover, all strains were similar in size, shape and general appearance (Figs. 5-12). Cells of all strains were small (cell length of about $10-20 \mu \mathrm{m}$, Table 2) and ovoid to elliptical in shape. Typically, the episome was slightly larger than the hyposome, with convex sides ending in a distinctly pointed apex which was clearly visible in LM. For all strains the cingulum was deep and wide, accounting for roughly $1 / 5$ to $1 / 4$ of the cell length. Cells of all strains had a central or more posterior located large and round to elliptical nucleus and a presumably single chloroplast which was parietally arranged, lobed and which normally extended into both the epi- and hyposome. Despite all superficial similarities, seven species could be differentiated based on specific morphological characteristics described below.

3.2.1.1. Amphidoma languida. A total of 13 strains of Am. languida were obtained from stations covering almost the whole area of investigation, from the Skagerrak off Mandal (station 1) to station 44 in the north off Ålesund. All strains of Am. languida shared an identical morphology as observed in LM (Fig. 5). In accordance with the species description (Tillmann et al., 2012a), cells consistently had one large pyrenoid with a starch sheath (visible as a ring-like structure) located in the episome (Fig. 5A, C). Detailed SEM performed for a selected number of strains (Table 2) revealed the Kofoidean plate pattern of Po, cp, X, 6', 0a, 6",

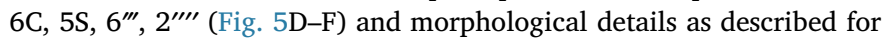
the type material. A ventral pore was located at the right side of plate $1^{\prime}$ close to the pore plate (Fig. 5G). On the hypotheca a large antapical pore was located on the second antapical plate (Fig. 5F). A number of, but not all, cells in the clonal cultures had a round ventral depression located at the anterior tip of the anterior sulcal plate (Fig. 5F).

3.2.1.2. Azadinium obesum. One strain of Az. obesum was obtained from station 45 off Molde, and the morphology in all aspects was consistent with the type material (Tillmann et al., 2010). No pyrenoid was visible in the cell of this strain using light microscopy (Fig. 6A-D). A detailed SEM examination revealed the Kofoidean plate pattern (Po, cp, X, 4', $\left.3 \mathrm{a}, 6^{\prime \prime}, 6 \mathrm{C}, 5 \mathrm{~S}, 6^{\prime \prime \prime}, 2^{\prime \prime \prime \prime}\right)$ and plate size and arrangement as described for the type strain (Fig. 6E-H). As a distinctive morphological feature, the 




Fig. 3. On board live sample LM records of Amphidomataceae along the Norwegian coast. Note that not all stations were inspected and that samples were not checked with the same level of time and effort, so a lack of record does not mean absence of Amphidomataceae at this station, and the number of cells depicted are not reflective of quantitative abundance. Scale bars $=2 \mu \mathrm{m}$.

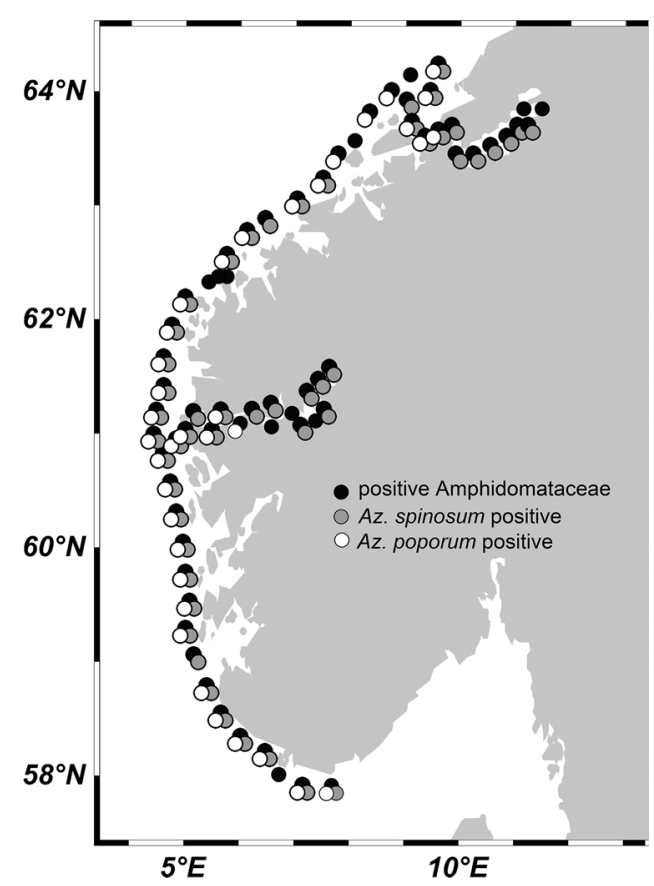

Fig. 4. Real-time PCR presence/absence of positive signals using the Amphidomataceae general probe (black circles), and the probes specific for Azadinium spinosum (grey circles) or Az. poporum (white circles). ventral pore was located ventrally at the margin of plate $1^{\prime}$ and $1^{\prime \prime}$. Plate $1^{\prime}$ had a narrow posterior part (Fig. 6H). Epithecal intercalary plates were relatively small and the first of them (1a) was not in contact with plate 1" (Fig. 6F).

3.2.1.3. Azadinium dalianense. Five of the strains were identified as $A z$. dalianense and were isolated from the area south of the Sognefjorden (Stat. 12 and 15) or around Ulsteinvik (Stat. 39 and 42). They all shared the same morphological features described as distinctive for $A z$. dalianense (Luo et al., 2016). The general shape was characteristic as the hypotheca was asymmetrically pointed with a small bulb (Fig. 7). At the end of this bulb there occasionally was a small spine visible in LM (Fig. 7A). One pyrenoid was consistently located posterior in the hyposome (Fig. 7D), which in living cells was sometimes difficult to see. Electron microscopy performed for four of the strains revealed the distinctive epithecal plate pattern of this species which consisted of only three apical plates and two large anterior intercalary plates (Fig. 7F). Of the latter, plate 1a was pentagonal and slightly larger than the hexagonal plate 2a. Consistent with the species description plate $2^{\prime \prime}$ and $4^{\prime \prime}$ of the precingular series were distinctly smaller compared to the other precingular plates (Fig. 7F). The ventral pore was located at the junction of the plates Po, $1^{\prime}$ and $2^{\prime}$ (Fig. 7H). Cells of all four strains examined by SEM had an antapical spine located on the large antapical plate $2^{\prime \prime \prime \prime}$ (Fig. 7G). As it was described for the type strain, size and development of the spine was quite variable ranging from well-developed to only rudimentary presence, and a significant proportion of cells of all strains lacked any signs of a spine. A 
Table 2

Strain information $(\mathrm{LM}=$ light microscopy, SEM $=$ scanning electron microscopy, SSU $=$ small subunit rDNA, LSU $=$ large subunit rDNA, ITS $=$ internal transcribed spacer, $\mathrm{ND}=$ not detected, $-=$ not analysed.

\begin{tabular}{|c|c|c|c|c|c|c|c|c|c|c|c|c|}
\hline \multirow{3}{*}{$\begin{array}{l}\text { Species } \\
\text { Az. dalianensen }\end{array}$} & \multirow{3}{*}{$\begin{array}{l}\text { Strain } \\
\mathrm{N}-12-04\end{array}$} & \multirow{3}{*}{$\begin{array}{l}\text { Origin } \\
\text { Station } \\
\\
12\end{array}$} & \multirow{3}{*}{$\begin{array}{l}\text { Length }(\mu \mathrm{m}) \\
\begin{array}{l}\text { Mean } \pm \mathrm{SD} \\
\text { Min-max }\end{array} \\
\begin{array}{l}15.0 \pm 1.1 \\
12.2-16.9\end{array}\end{array}$} & \multirow{3}{*}{$\begin{array}{l}\text { Width }(\mu \mathrm{m}) \\
\begin{array}{l}\text { Mean } \pm \mathrm{SD} \\
\text { Min-max }\end{array} \\
\begin{array}{l}10.7 \pm 0.9 \\
8.4-12.8\end{array}\end{array}$} & \multirow{3}{*}{$\begin{array}{l}\text { l/w ratio } \\
\text { Mean } \pm S D \\
1.40 \pm 0.06\end{array}$} & \multirow{3}{*}{$\begin{array}{l}\mathrm{N} \\
\\
\\
68\end{array}$} & \multicolumn{2}{|c|}{ Morphological analysis } & \multicolumn{3}{|c|}{ Sequence data } & \multirow{3}{*}{$\begin{array}{l}\text { AZA } \\
\\
\text { ND }\end{array}$} \\
\hline & & & & & & & & & & & & \\
\hline & & & & & & & LM & SEM & - & LSU & ITS & \\
\hline Az. dalianense & N-15-01 & 15 & $\begin{array}{l}14.8 \pm 0.9 \\
12.2-16.5\end{array}$ & $\begin{array}{l}10.5 \pm 0.7 \\
8.9-12.2\end{array}$ & $1.41 \pm 0.08$ & 118 & LM & SEM & SSU & LSU & ITS & ND \\
\hline Az. dalianense & N-38c-01 & 42 & $\begin{array}{l}14.3 \pm 1.0 \\
12.0-16.6\end{array}$ & $\begin{array}{l}10.1 \pm 0.8 \\
8.5-11.6\end{array}$ & $1.41 \pm 0.07$ & 72 & LM & - & - & - & - & ND \\
\hline Az. dalianense & N-38-02 & 39 & $\begin{array}{l}15.2 \pm 0.9 \\
13.3-17.2\end{array}$ & $\begin{array}{l}10.8 \pm 0.8 \\
9.4-12.3\end{array}$ & $1.41 \pm 0.08$ & 57 & LM & SEM & SSU & LSU & ITS & ND \\
\hline Az. dalianense & N-38-03 & 39 & $\begin{array}{l}14.9 \pm 0.9 \\
12.4-16.6\end{array}$ & $\begin{array}{l}10.3 \pm 0.6 \\
8.7-11.7\end{array}$ & $1.45 \pm 0.06$ & 57 & LM & SEM & SSU & LSU & ITS & ND \\
\hline Az. obesum & N-41-01 & 45 & $\begin{array}{l}16.2 \pm 1.0 \\
14.0-18.2\end{array}$ & $\begin{array}{l}12.9 \pm 1.3 \\
10.1-15.6\end{array}$ & $1.27 \pm 0.08$ & 53 & LM & SEM & SSU & LSU & - & ND \\
\hline Az. trinitatum & N-39-04 & 43 & $\begin{array}{l}15.4 \pm 1.0 \\
13.5-18.0\end{array}$ & $\begin{array}{l}10.6 \pm 0.8 \\
9.0-12.3\end{array}$ & $1.45 \pm 0.05$ & 58 & LM & SEM & SSU & LSU & ITS & ND \\
\hline Az. polongum & N-47-01 & 51 & $\begin{array}{l}15.0 \pm 1.1 \\
10.6-16.8\end{array}$ & $\begin{array}{l}11.9 \pm 0.9 \\
10.0-14.7\end{array}$ & $1.27 \pm 0.10$ & 53 & LM & SEM & SSU & LSU & ITS & ND \\
\hline Am. languida & N-01-01 & 1 & $\begin{array}{l}14.1 \pm 0.8 \\
12.3-16.1\end{array}$ & $\begin{array}{l}11.0 \pm 1.0 \\
9.3-14.9\end{array}$ & $1.28 \pm 0.07$ & 62 & LM & SEM & - & LSU & - & AZA-38, -39 \\
\hline Am. languida & N-04-03 & 4 & - & - & - & - & LM & - & - & LSU & - & AZA-38, -39 \\
\hline Am. languida & N-12-01 & 12 & $\begin{array}{l}14.5 \pm 1.1 \\
12.1-16.9\end{array}$ & $\begin{array}{l}11.3 \pm 0.8 \\
8.6-12.8\end{array}$ & $1.29 \pm 0.07$ & 79 & LM & SEM & - & - & - & AZA-38, -39 \\
\hline Am. languida & N-14-01 & 14 & - & - & - & - & LM & - & - & LSU & - & AZA-38, -39 \\
\hline Am. languida & N-33-01 & 34 & - & - & - & - & LM & SEM & SSU & LSU & - & AZA-38, -39 \\
\hline Am. languida & N-37-01 & 38 & $\begin{array}{l}13.8 \pm 1.0 \\
11.7-16.7\end{array}$ & $\begin{array}{l}10.8 \pm 0.9 \\
9.1-13.2\end{array}$ & $1.28 \pm 0.06$ & 82 & LM & SEM & SSU & LSU & - & AZA-38, -39 \\
\hline Am. languida & N-38-01 & 38 & - & - & - & - & LM & - & SSU & LSU & - & AZA-38, -39 \\
\hline Am. languida & N-39-06 & 43 & - & - & - & - & LM & SEM & SSU & LSU & - & AZA-38, -39 \\
\hline Am. languida & N-39-07 & 43 & - & - & - & - & LM & SEM & SSU & LSU & - & AZA-39, -53 \\
\hline Am. languida & N-39-12 & 43 & $\begin{array}{l}13.6 \pm 0.9 \\
11.3-15.7\end{array}$ & $\begin{array}{l}10.6 \pm 0.9 \\
8.6-13.8\end{array}$ & $1.28 \pm 0.07$ & 65 & LM & SEM & SSU & LSU & - & AZA-38, -39 \\
\hline Am. languida & N-40-03 & 44 & $\begin{array}{l}13.9 \pm 1.0 \\
11.4-16.4\end{array}$ & $\begin{array}{l}10.5 \pm 0.9 \\
8.5-12.6\end{array}$ & $1.33 \pm 0.08$ & 132 & LM & SEM & SSU & LSU & - & AZA-39, -52 \\
\hline Am. languida & N-40-04 & 44 & $\begin{array}{l}14.0 \pm 1.0 \\
12.2-16.3\end{array}$ & $\begin{array}{l}10.7 \pm 1.0 \\
8.9-13.0\end{array}$ & $1.31 \pm 0.07$ & 85 & LM & - & SSU & LSU & - & AZA-38, -39 \\
\hline Am. languida & N-40-06 & 44 & $\begin{array}{l}15.9 \pm 1.0 \\
13.6-16.7\end{array}$ & $\begin{array}{l}12.1 \pm 0.9 \\
10.6-13.5\end{array}$ & $1.24 \pm 0.06$ & 13 & LM & - & SSU & LSU & - & AZA-39, -53 \\
\hline Az. poporum & N-39-01 & 43 & $\begin{array}{l}15.9 \pm 1.4 \\
12.8-19.5\end{array}$ & $\begin{array}{l}11.3 \pm 1.1 \\
9.0-14.4\end{array}$ & 1.410 .06 & 51 & LM & SEM & - & - & - & AZA-37 \\
\hline Az. poporum & N-39-03 & 43 & $\begin{array}{l}15.4 \pm 1.3 \\
12.7-19.2\end{array}$ & $\begin{array}{l}11.1 \pm 1.0 \\
9.2-14.6\end{array}$ & $1.39 \pm 0.05$ & 50 & LM & SEM & SSU & - & ITS & AZA-37 \\
\hline Az. poporum & N-39-13 & 43 & $\begin{array}{l}15.8 \pm 1.2 \\
12.8-18.2\end{array}$ & $\begin{array}{l}11.2 \pm 0.8 \\
9.2-13.2\end{array}$ & $1.41 \pm 0.06$ &. .50 & LM & SEM & - & LSU & ITS & AZA-37 \\
\hline Az. spinosum & N-04-01 & 4 & $\begin{array}{l}14.9 \pm 1.9 \\
12.7-17.6\end{array}$ & $\begin{array}{l}10.1 \pm 0.9 \\
8.3-13.0\end{array}$ & $1.47 \pm 0.07$ & 121 & LM & SEM & SSU & LSU & ITS & AZA-1, $-2,-33$ \\
\hline Az. spinosum & N-04-02 & 4 & - & - & - & - & LM & SEM & SSU & LSU & ITS & AZA-1, $-2,-33$ \\
\hline Az. spinosum & N-04-04 & 4 & $\begin{array}{l}16.4 \pm 1.0 \\
14.1-18.6\end{array}$ & $\begin{array}{l}10.8 \pm 0.9 \\
9.0-12.8\end{array}$ & $1.52 \pm 0.08$ & 55 & LM & SEM & SSU & LSU & - & AZA-11, -51 \\
\hline Az. spinsoum & N-05-01 & 5 & $\begin{array}{l}15.4 \pm 1.0 \\
13.6-17.3\end{array}$ & $\begin{array}{l}10.1 \pm 0.8 \\
8.9-11.6\end{array}$ & $1.54 \pm 0.06$ & 56 & LM & SEM & SSU & LSU & ITS & AZA-11, -51 \\
\hline Az. spinosum & N-05-02 & 5 & $\begin{array}{l}16.8 \pm 1.2 \\
14.4-20.0\end{array}$ & $\begin{array}{l}11.2 \pm 1.1 \\
9.0-14.5\end{array}$ & $1.51 \pm 0.070$ & 107 & LM & SEM & SSU & LSU & ITS & AZA-11, -51 \\
\hline Az. spinosum & N-14-02 & 14 & $\begin{array}{l}16.4 \pm 1.1 \\
13.9-19.0\end{array}$ & $\begin{array}{l}10.5 \pm 0.9 \\
8.3-12.5\end{array}$ & $1.57 \pm 0.10$ & 127 & LM & SEM & - & LSU & ITS & AZA-11, $-51,-50$ \\
\hline Az. spinosum & N-16-01 & 16 & $\begin{array}{l}15.9 \pm 0.9 \\
13.4-18.5\end{array}$ & $\begin{array}{l}10.2 \pm 0.7 \\
8.7-11.8\end{array}$ & $1.56 \pm 0.0$ & 145 & LM & SEM & - & LSU & ITS & AZA-51 \\
\hline Az. spinosum & N-16-02 & 16 & $\begin{array}{l}16.4 \pm 1.0 \\
13.4-20.2\end{array}$ & $\begin{array}{l}10.8 \pm 0.7 \\
8.8-12.4\end{array}$ & $1.52 \pm 0.07$ & 54 & LM & SEM & SSU & - & ITS & AZA-11, -51 \\
\hline Az. spinosum & N-39-02 & 43 & $\begin{array}{l}15.8 \pm 1.1 \\
13.3-18.9\end{array}$ & $\begin{array}{l}10.0 \pm 0.8 \\
83-12.4\end{array}$ & $1.58 \pm 0.08$ & 113 & LM & SEM & - & - & ITS & AZA-11, -51 \\
\hline
\end{tabular}

quantification of the frequency of spine presence ( $n=100$ cells) revealed a proportion of cells without spine of $25 \%$ (strain N-12-04), $22 \%$ (strains N-15-01) and 14\% (strain N-38-03). For strain N-38-02, two estimates of spine prevalence of independently grown cultures revealed $11 \%$ and $19 \%$ of cells without spine, respectively.

3.2.1.4. Azadinium poporum. Three strains of Az. poporum were obtained from station 43 off Ålesund. All Az. poporum strains were indistinguishable and all morphological details revealed through light and electron microscopy were not different from the original species description (Tillmann et al., 2011). Cells were variable in size (Table 2). There was no antapical spine, and pyrenoid(s) were always present in the cell and were located in the episome and/or the hyposome (Fig. 8). The number of visible pyrenoids per cell was at least one but two pyrenoids were observed more frequently (Fig. 8A). Detailed SEM revealed the Kofoidean plate pattern as Po, cp, X, 4', 3a, 6", 6C, 5S, 6"', 


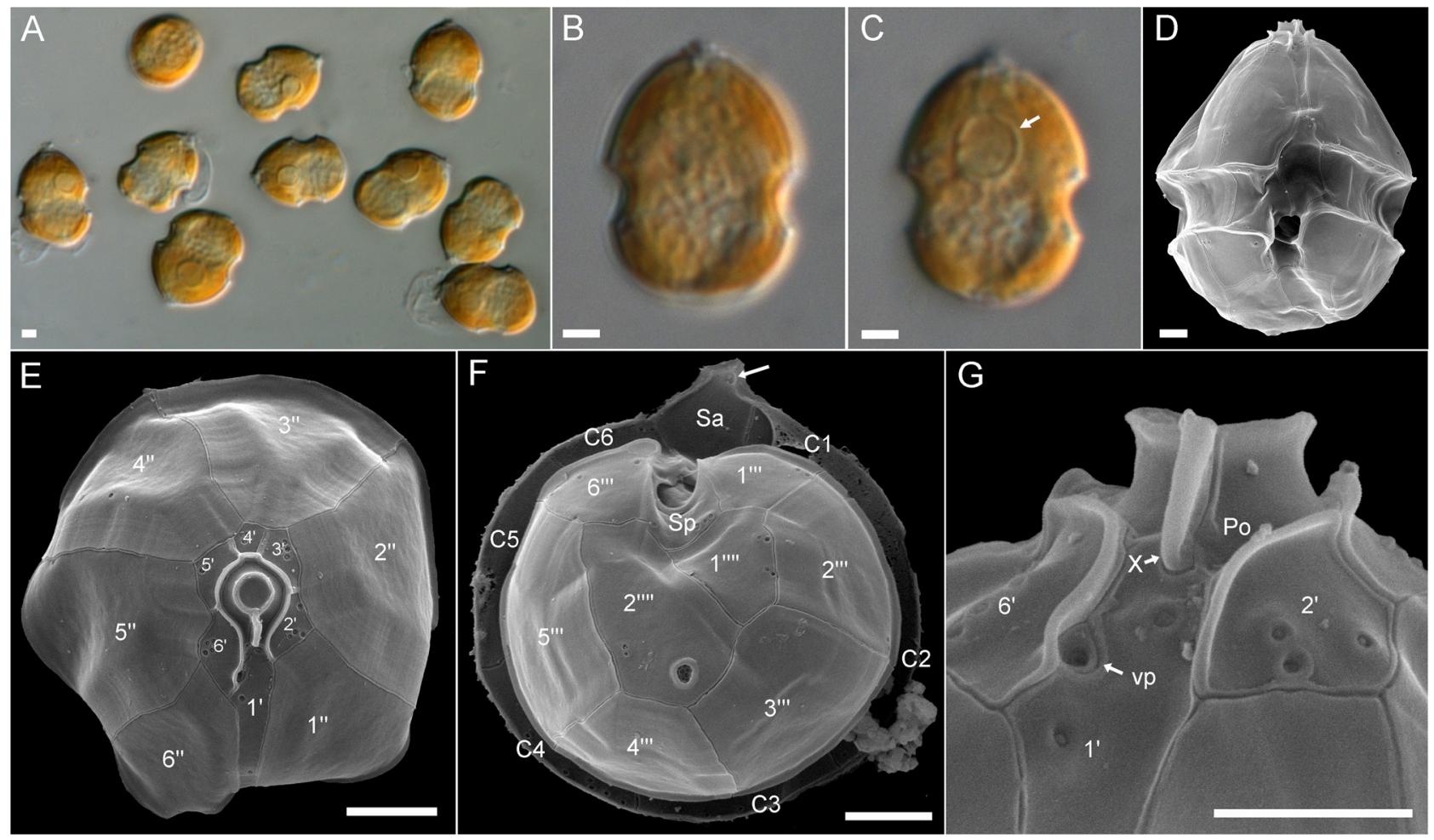

Fig. 5. Amphidoma languida (strain N-40-03). (A-C) LM of (A) formaldehyde fixed cells showing general size and shape and (B-C) living cells; note the presence of one large pyrenoid (arrow in C). (D-G) SEM of different cells in (D) ventral view, (E) apical view, (F) antapical view. Note the ventral depression (arrow) at the anterior tip of the anterior sulcal plate. $(\mathrm{G})$ Detailed ventral view of the apical pore complex. Plate labels according to the Kofoidean system. Po $=$ pore plate, $\mathrm{X}=\mathrm{X}$ plate, $v p=$ ventral pore. Scale bars $=2 \mu \mathrm{m}(\mathrm{A}-\mathrm{F})$ or $1 \mu \mathrm{m}(\mathrm{G})$.
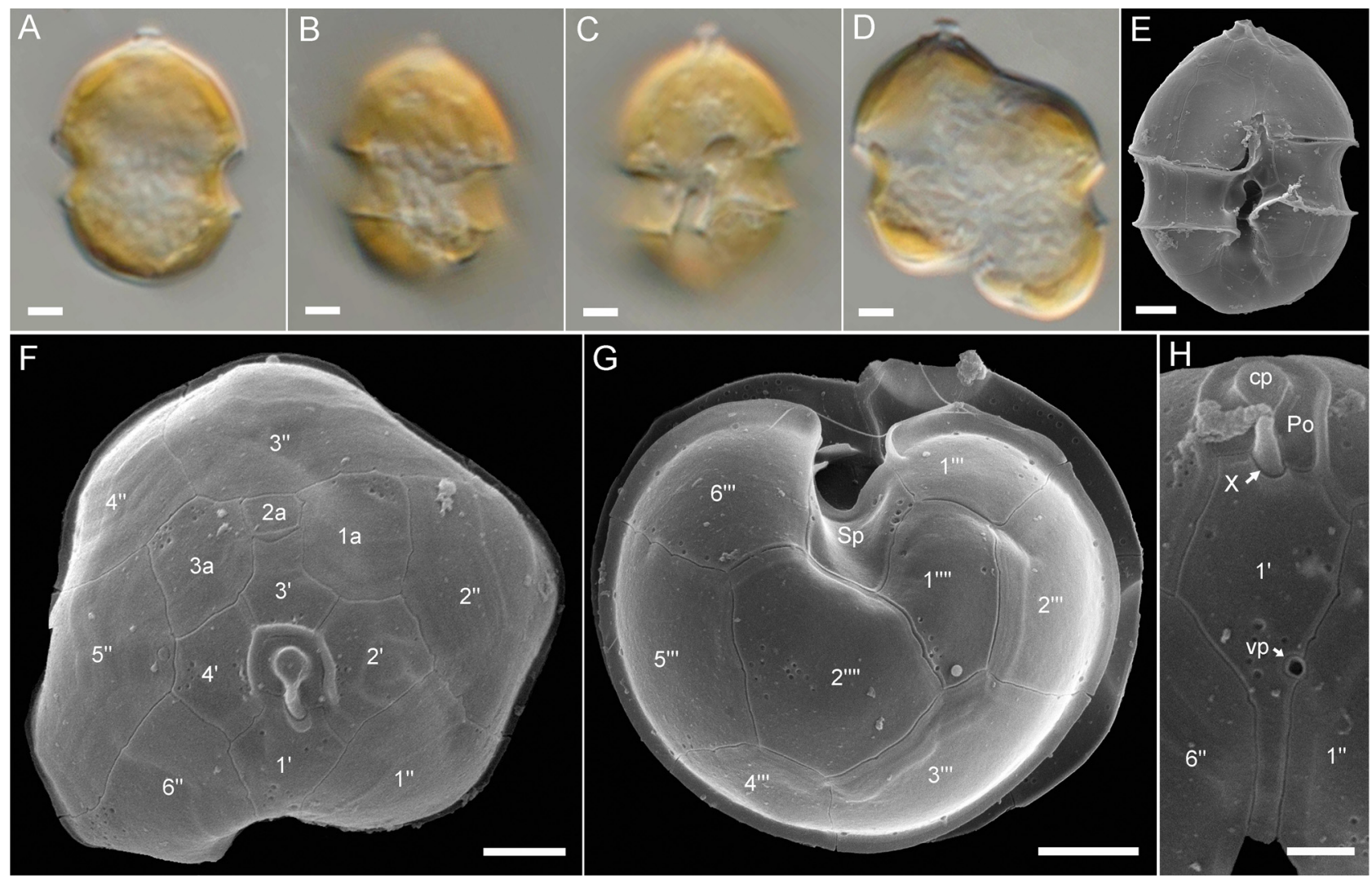

Fig. 6. Azadinium obesum (strain N-41-01). (A-D) LM living cells. A-C same cell with (A) a middle, (B) dorsal, or (C) ventral focal plane. (D) Dividing cell in dorsal view. (E-H) SEM of different cells in (E) ventral view, (F) apical view, (G) antapical view. (H) Detailed ventral view of the first apical plate and the apical pore complex. Plate labels according to the Kofoidean system. $\mathrm{Po}=$ pore plate, $\mathrm{cp}=$ cover plate, $\mathrm{X}=\mathrm{X}$-plate, $\mathrm{vp}=$ ventral pore. Scale bars $=2 \mu \mathrm{m}(\mathrm{A}-\mathrm{G})$ or $1 \mu \mathrm{m}(\mathrm{H})$. 


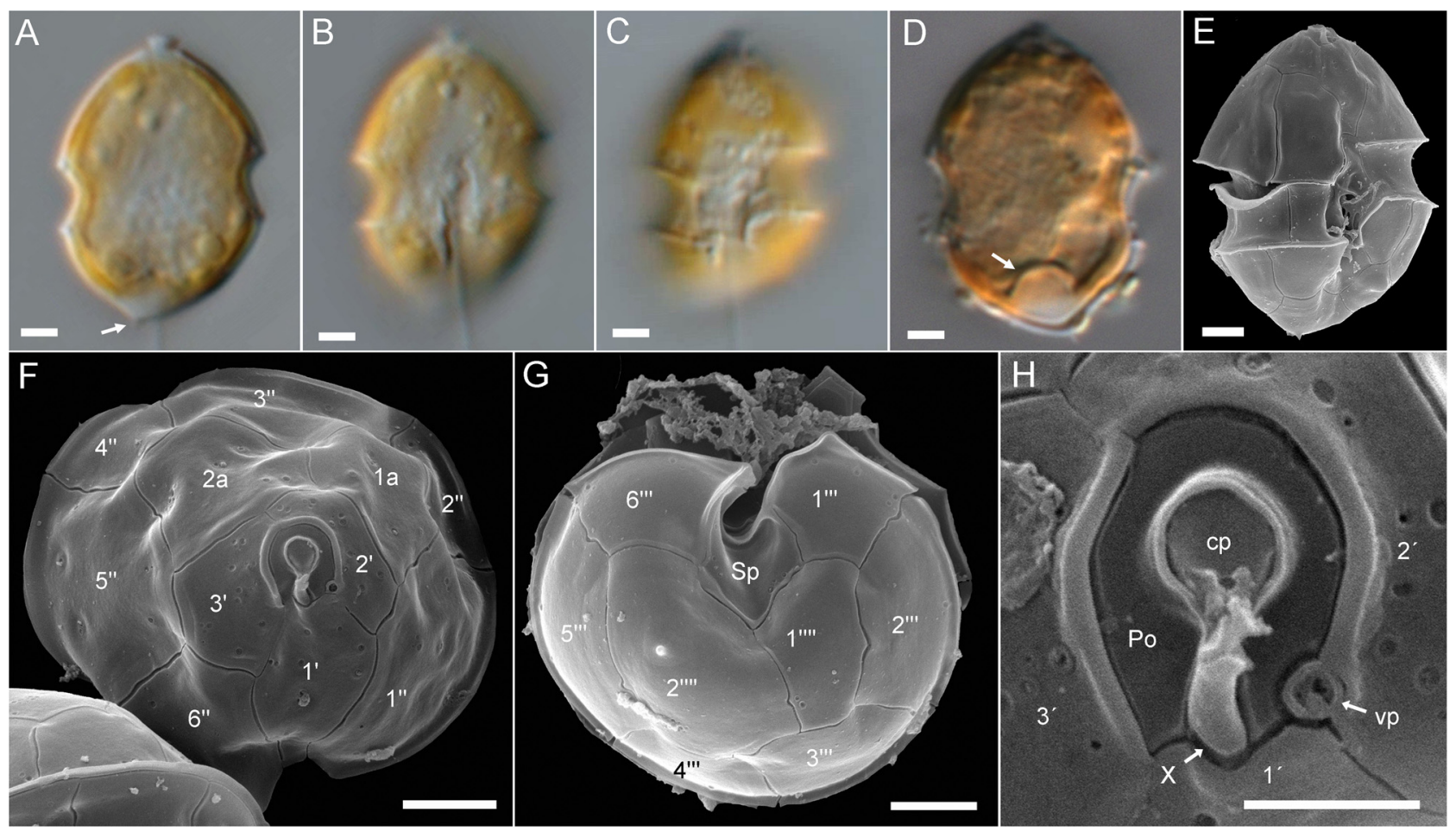

Fig. 7. Azadinium dalianense (strain N-12-04). (A-D) LM of (A-C) living or (D) formaldehyde fixed cells showing general size and shape; note the presence of one small antapical spine (arrow in A) and of one large pyrenoid in the hyposome (arrow in D). (E-H) SEM of different cells in (D) ventral lateral view, (F) apical view, (G) antapical view. $(\mathrm{H})$ Detailed apical view of the apical pore complex. Plate labels according to the Kofoidean system. Po $=$ pore plate, $\mathrm{cp}=\mathrm{cover}$ plate, $\mathrm{X}=\mathrm{X}$-plate, $\mathrm{vp}=$ ventral pore. Scale bars $=2 \mu \mathrm{m}(\mathrm{A}-\mathrm{G})$ or $1 \mu \mathrm{m}(\mathrm{H})$.

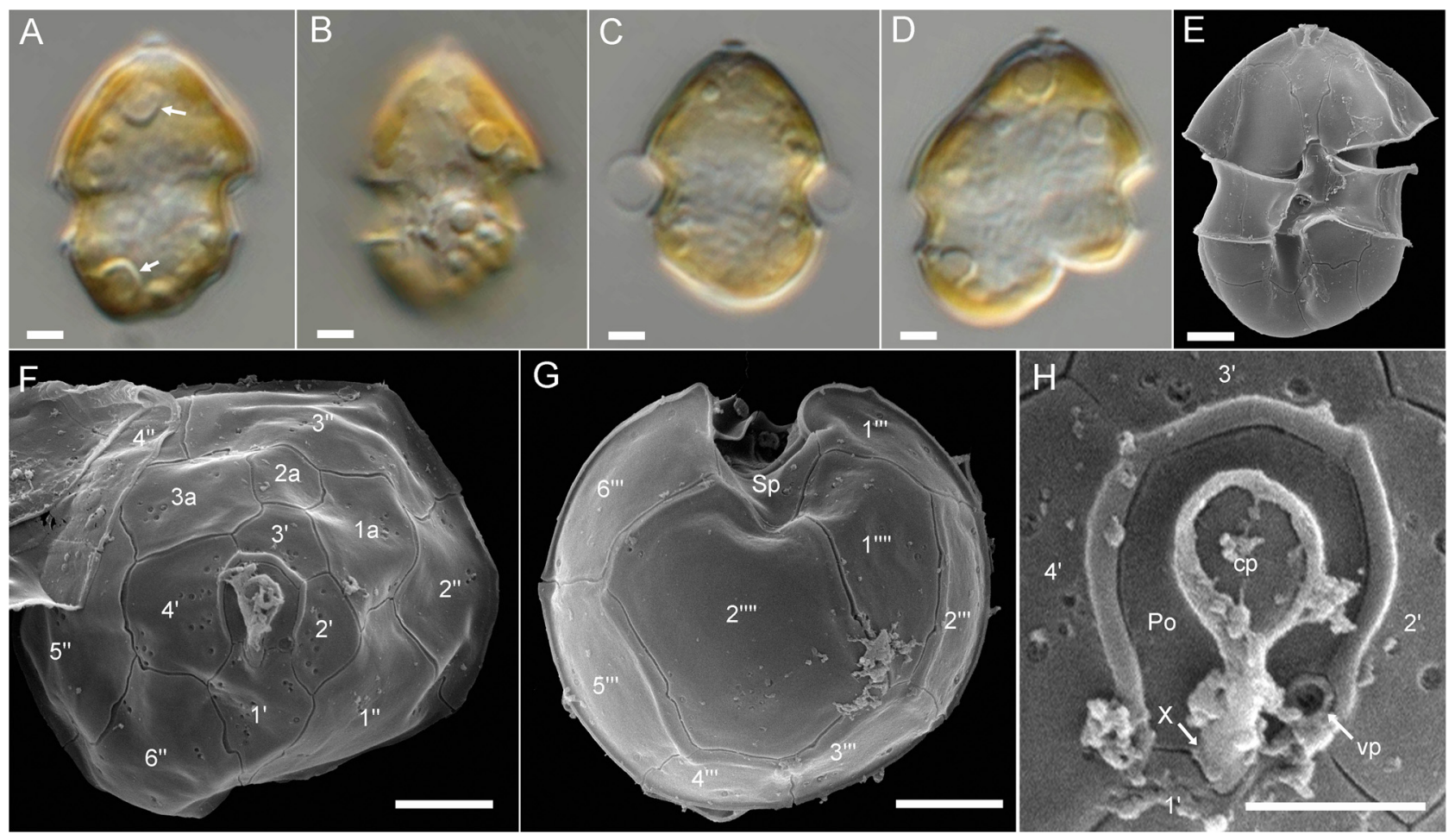

Fig. 8. Azadinium poporum (strain N-39-13). (A-D) LM of living cells; note the presence of pyrenoids both in epi- and hyposome (arrows in A). (D) Dividing cell in ventral view. (E-H) SEM of different cells in (E) ventral view, (F) apical view, (G) antapical view. (H) Detailed apical view of the apical pore complex. Plate labels according to the Kofoidean system. Po $=$ pore plate, $\mathrm{cp}=$ cover plate, $\mathrm{X}=\mathrm{X}$-plate, $\mathrm{vp}=$ ventral pore. Scale bars $=2 \mu \mathrm{m}(\mathrm{A}-\mathrm{G})$ or $1 \mu \mathrm{m}(\mathrm{H})$. 


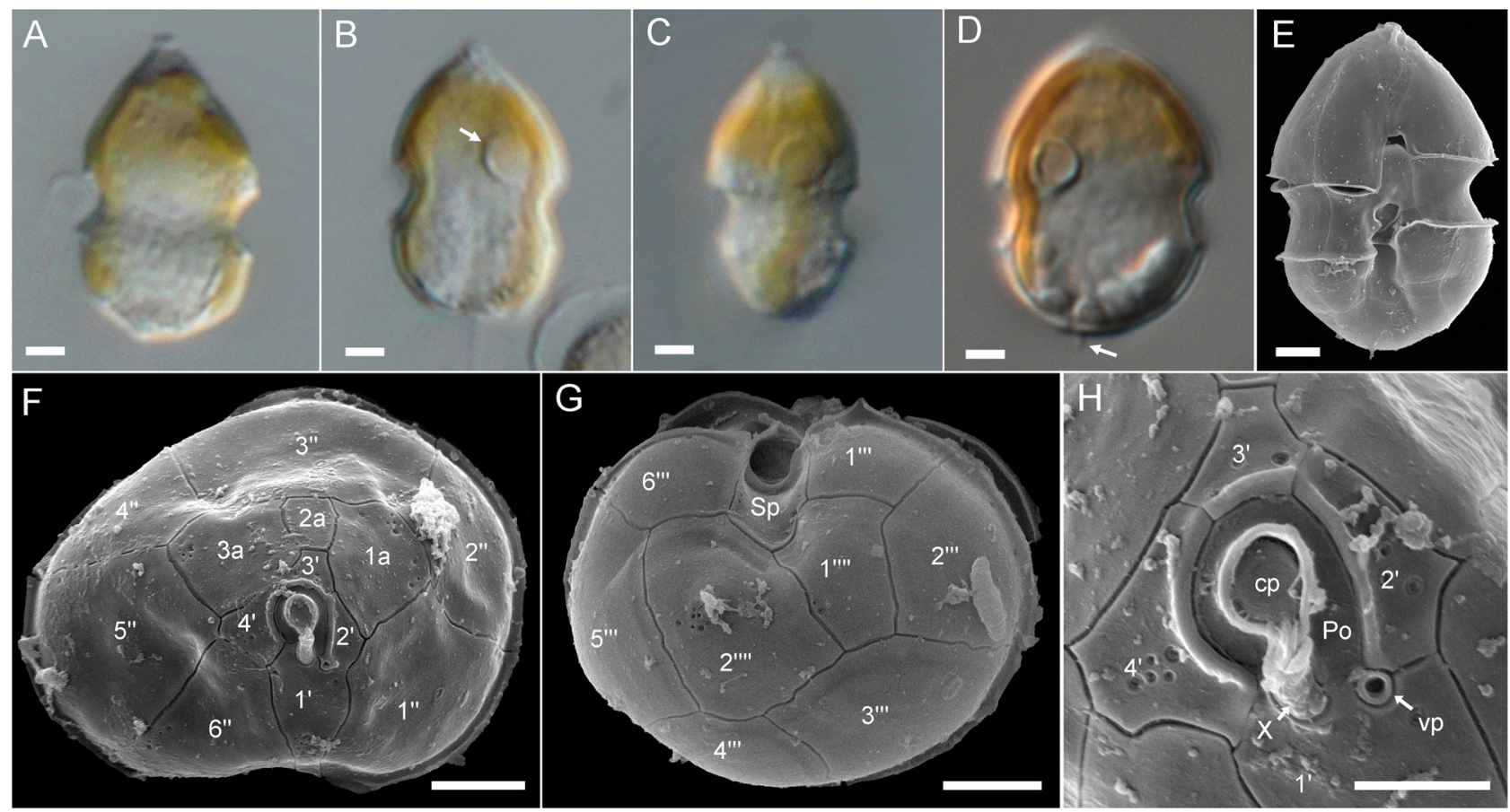

Fig. 9. Azadinium trinitatum (strain N-39-04). (A-D) LM of (A-C) living or (D) formaldehyde fixed cells showing general size and shape; note the presence of one large pyrenoide in the episome (arrow in B) and the presence of an antapical spine (arrow in D). (E-H) SEM of different cells in (E) ventral view, (F) apical view, (G) antapical view. $(\mathrm{H})$ Detailed apical view of the apical pore complex. Plate labels according to the Kofoidean system. Po $=$ pore plate, $\mathrm{cp}=\mathrm{cover}$ plate, $\mathrm{X}=\mathrm{X}$-plate, $\mathrm{vp}=$ ventral pore. Scale bars $=2 \mu \mathrm{m}(\mathrm{A}-\mathrm{G})$ or $1 \mu \mathrm{m}(\mathrm{H})$.

$2^{\prime \prime \prime \prime}$ (Fig. 8E-H). Cells of all strains conformed to the original Az. poporum description with respect to the position of the ventral pore, which was located at the junction of the pore plate and the first two apical plates (Fig. $8 \mathrm{H}$ ). The larger right antapical plate $2^{\prime \prime \prime \prime}$ typically had a group of pores on the dorsal side (Fig. 8G).
3.2.1.5. Azadinium trinitatum. One single strain of Az. trinitatum was obtained from station 43 off Ålesund. It conformed to the morphology of the type strain described by Tillmann et al. (2014a). Cells were variable in shape with an epitheca ranging from conical to more domeshaped. In LM (Fig. 9A-D) one pyrenoid located in the hyposome
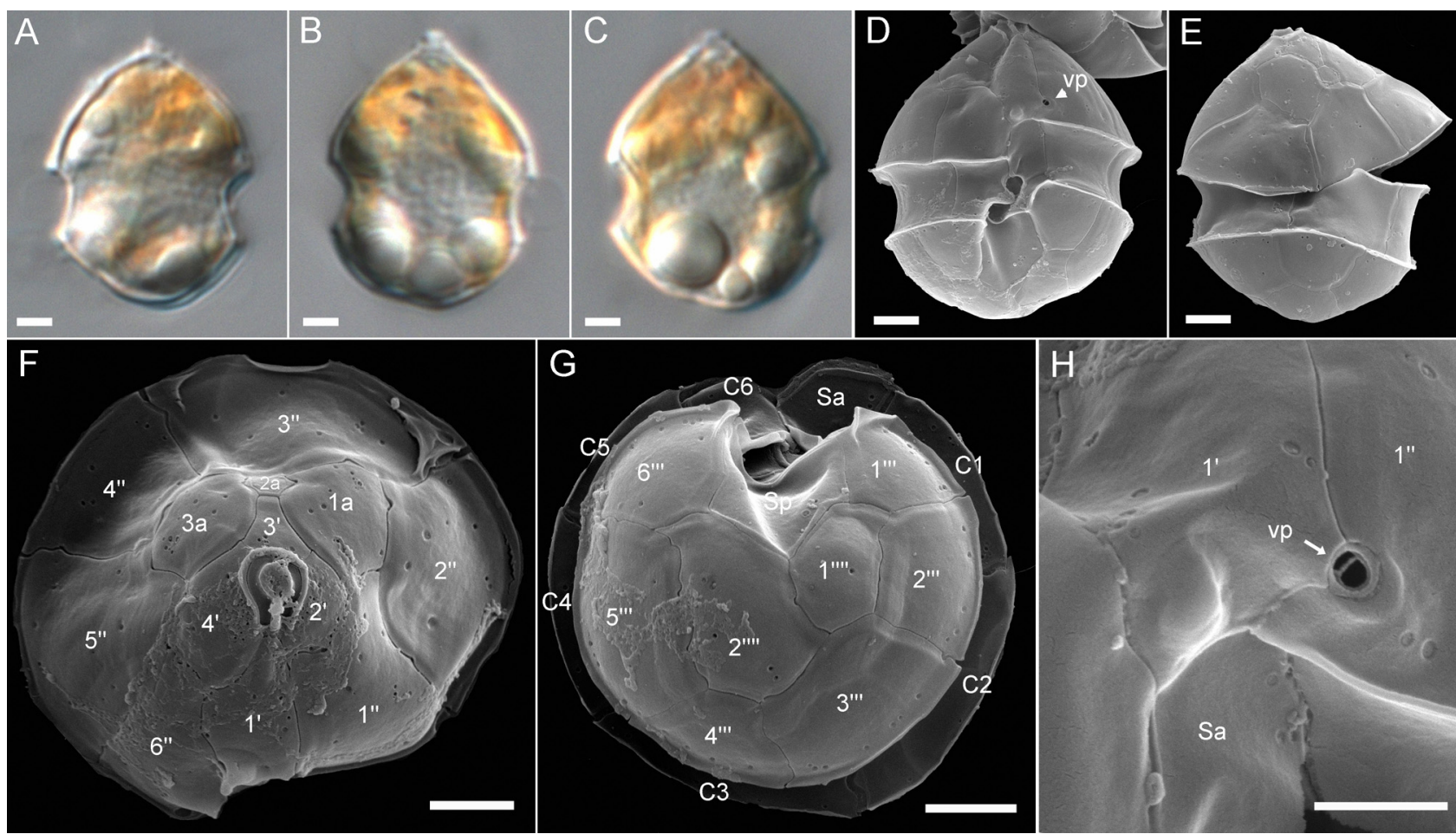

Fig. 10. Azadinium polongum (strain N-47-01). (A-C) LM of formaldehyde fixed cells showing general size and shape. (D-H) SEM of different cells in (D) ventral view, (E) dorsal view, (F) apical view, (G) antapical view. (H) Detailed ventral view of the first apical plate and the ventral pore. Plate labels according to the Kofoidean system. vp $=$ ventral pore. Scale bars $=2 \mu \mathrm{m}(\mathrm{A}-\mathrm{G})$ or $1 \mu \mathrm{m}(\mathrm{H})$. 


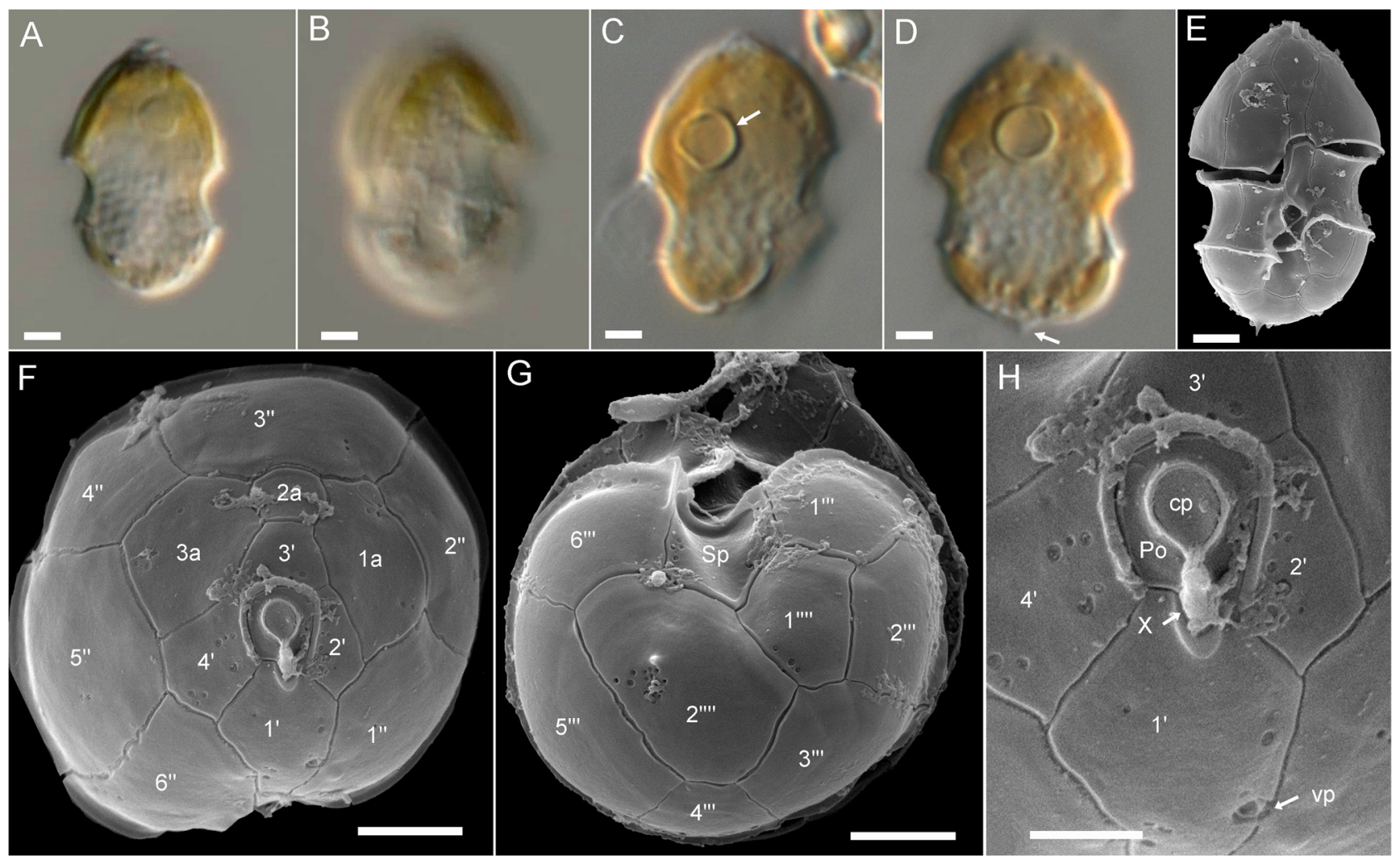

Fig. 11. Azadinium spinosum (strain N-04-01). (A-D) LM of (A-C) living or (D) formaldehyde fixed cells showing general size and shape; note the presence of one large pyrenoid in the episome (arrow in C) and the presence of an antapical spine (arrow in D). (E-H) SEM of different cells in (E) ventral view, (F) apical view, (G) antapical view. $(\mathrm{H})$. Detailed ventral view of the first apical plate and the apical pore complex. Plate labels according to the Kofoidean system. Po $=$ pore plate, $\mathrm{cp}=$ cover plate, $\mathrm{X}=\mathrm{X}$-plate, $\mathrm{vp}=$ ventral pore. Scale bars $=2 \mu \mathrm{m}(\mathrm{A}-\mathrm{G})$ or $1 \mu \mathrm{m}(\mathrm{H})$.
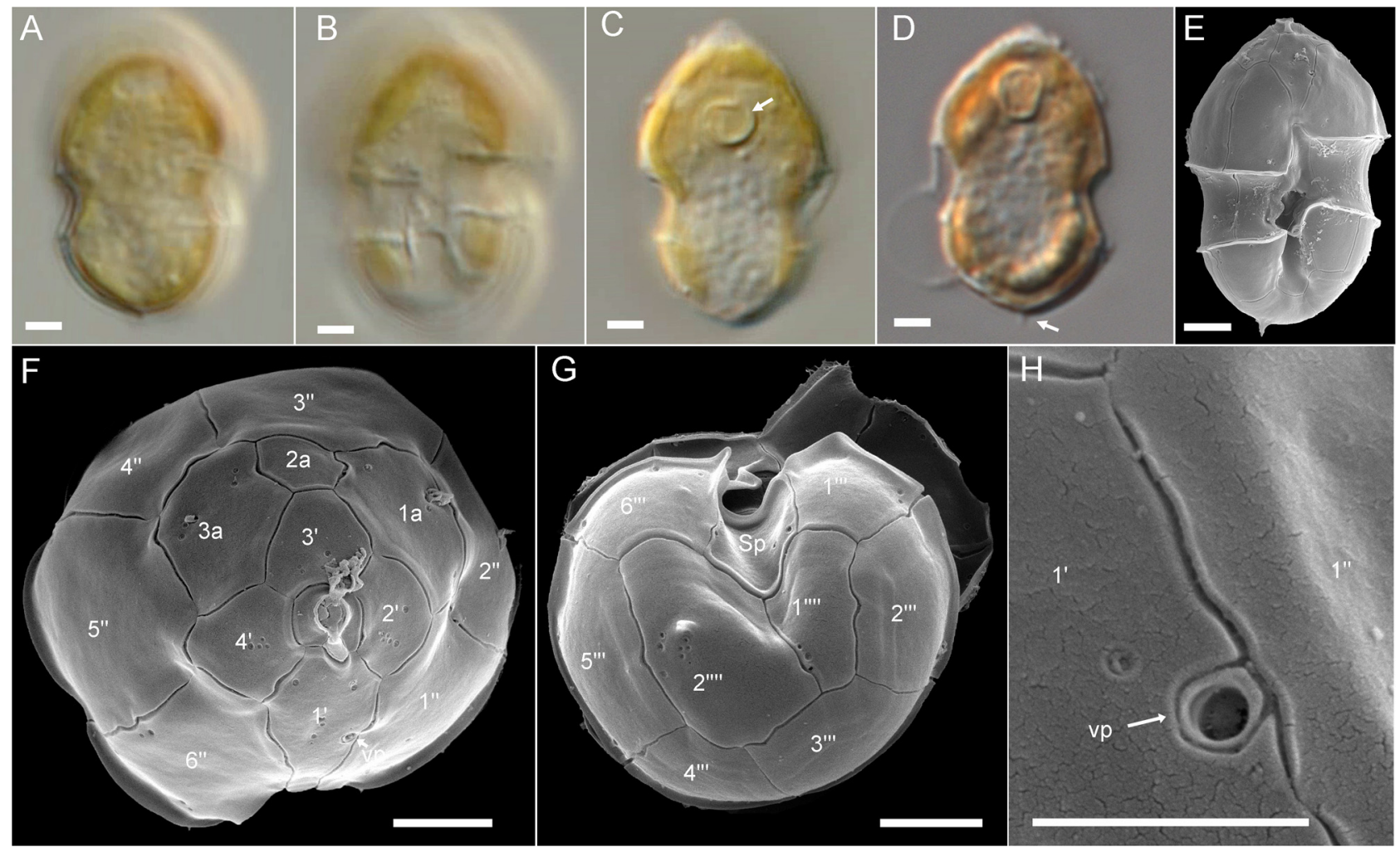

Fig. 12. Azadinium spinosum (strain N-05-01). (A-D) LM of (A-C) living or (D) formaldehyde fixed cells showing general size and shape; note the presence of one large pyrenoid in the episome (arrow in C) and the presence of an antapical spine (arrow in D). (E-H) SEM of different cells in (E) ventral view, (F) apical view, (G) antapical view. $(\mathrm{H})$. Detailed ventral view of the first apical plate and the ventral pore. Plate labels according to the Kofoidean system. vp $=$ ventral pore. Scale bars $=2 \mu \mathrm{m}(\mathrm{A}-\mathrm{G})$ or $1 \mu \mathrm{m}(\mathrm{H})$. 
(Fig. 9B), and the presence of a small antapical spine (Fig. 9D) was visible. Scanning electron microscopy examination (Fig. 9E-H) conformed the presence of relatively small apical plates, a broad contact of plates 1a and 1", and a group of pores next to the spine on plate $2^{\prime \prime \prime \prime}$. The ventral pore was located at the left lateral side of the pore plate in a cavity of the $1^{\prime}$ plate at the tip of an elongated side of a slightly asymmetric pore plate (Fig. $9 \mathrm{H})$.

3.2.1.6. Azadinium polongum. One strain (N-47-01) was identified as $A z$. polongum and originated from the Northern area (Station 51, off Frøya). In LM cells were broad (Fig. 10A-C) with a length/width ratio similar to other broad species such as $A z$. obesum and Am. languida (Table 2). The hyposome was slightly asymmetric and often filled with large granules (Fig. 10A-C). Scanning electron microscopy analysis (Fig. 10D-H) revealed important morphological details in accordance with the type material (Tillmann et al., 2012b). The small dorsal apical plate $3^{\prime}$ was elongated posterior, ending in a narrow tip that abutted the small intercalary plate 2a (Fig. 10F). The pore plate was slightly elongated. The ventral pore was located at the border of Plate $1^{\prime}$ and $1^{\prime \prime}$ at the lower third level of the epitheca in a cavity of plate $1^{\prime \prime}$ (Fig. 10D, H). Different to the type material, however, no antapical spine was present in strain N-47-01.

3.2.1.7. Azadinium spinosum. Strains of $A z$. spinosum were isolated from the southern area (Station 4 and 5, off Egersund), around the outer Sognefjorden area (Station 14 and 16), and from station 43 off Ålesund. All strains were indistinguishable by LM observation. Cells were variable in size and shape but generally slender with length/width rations of about 1.5 (Table 2). As described for the type strain (Tillmann et al., 2009), cells consistently had one distinct pyrenoid in the episome (Figs. 11C-D, $12 \mathrm{C}-\mathrm{D}$ ) and a small antapical spine was occasionally visible in LM (Figs. 11 D, 12 D). Scanning electron microscopy analysis for all strains (e.g. Figs. 11E-H, 12 E-H) conformed with morphological details as described for the type material, i.e. the presence of an antapical spine and a few scattered pores beneath, and a ventral pore located ventrally on the left side in a cavity of plate $1^{\prime}$. Among the 9 strains of Az. spinosum, however, slight differences in the structure of the apical pore complex were observed (Fig. 13). For strains N-04-01 and N-04-02, the pore plate was bordered by a distinct rim formed by the abutting apical plates, similar as it is observed for Az. spinosum type strain 3D9 (Fig. $13 \mathrm{~A}$ ). For the other Az. spinosum strain such a rim was consistently lacking or only rudimentary and partly hinted at (Fig. 13D-J).

\subsubsection{Phylogeny}

This study produced 65 sequences from 30 strains representing of 6 species of Azadinium and Amphidoma languida: 22 of SSU, 16 of ITS and 27 of partial LSU rDNA. The amplification and sequencing of the ITS1ITS2 region of Am. languida strains failed and was not examined further here. A phylogenetic tree was reconstructed by maximum likelihood analysis (PhyML) (Fig. 14). The phylogenetic placement of the Norwegian strains was according to their morphology. The 12 Amphidoma languida strains formed two clades, but with low support. Both $\mathrm{Az}$. poporum strains fell in the same well supported clade as two strains from Denmark (UTHD4 and UTHC8) of Ribotype A. The Az. dalianense strains fell in two different clades: one was placed together with strains from North Atlantic (France) and Northeast Pacific (USA) of Ribotype $B$, and three Norwegian strains clustered with strains from Northeast Pacific (USA) and Yellow Sea (China) of Ribotype A. Similarly, the strains of Az. spinosum in this study fell in two well supported clades. The genetic difference between these two clades was mostly in the ITS region within the rRNA operon. The Norwegian strains of $A z$. obesum, $A z$. trinitatum and $A z$. polongum clustered with strains of the same species from other areas.

\subsubsection{Toxin analysis of new strains}

No AZA were detected in both SRM and precursor mode in all strains of $A z$. dalianense and in the strains of $A z$. obesum, $A z$. trinitatum and $A z$. polongum (for the respective limits of detection see Suppl. Tab. S04).

Out of the nine Az. spinosum strains, two strains (N-04-01 and N-0402) showed the known AZA profile of $A z$. spinosum from the North Sea with the main compounds AZA-1, AZA-2 and AZA-33 (Table 2) at cell quotas of 0.2 to $6.6 \mathrm{fg} \mathrm{cell}^{-1}$ (Suppl. Tab. S1). One of the other $A z$. spinosum strains (N-14-02) displayed an AZA profile of AZA-11 and two unreported AZA named here AZA-50 ( $m / z$ 842) and AZA-51 $(m / z 858)$ (Table 2) at relatively low cell quotas of about 0.4 (AZA-11), 0.1 and $0.7 \mathrm{fg} \mathrm{cell}^{-1}$, respectively (expressed as AZA-1 equivalents, Suppl. Tab. S1). Of the remaining Az. spinosum strains, all produced AZA-51 (cell quota ranging from 0.2 to $5.2 \mathrm{fg}$ cell $^{-1}$, Suppl. Tab. S1), and additionally all but two (N-04-04 and N-39-02) contained AZA-11 (cell quota ranging from 0.1 to $0.7 \mathrm{fg}$ cell $^{-1}$, Suppl. Tab. S1) (Table 2).

For all AZA congeners detected in the Norwegian Az. spinosum strains (AZA-1, -2, -11, -33, -50, -51), the respective phosphates with a $80 \mathrm{Da}$ higher molecular mass were present. The peak areas of the phosphates were quite variable and ranged from $1 \%$ to $30 \%$ of the respective unphosphorylated AZA. As nothing is known about the
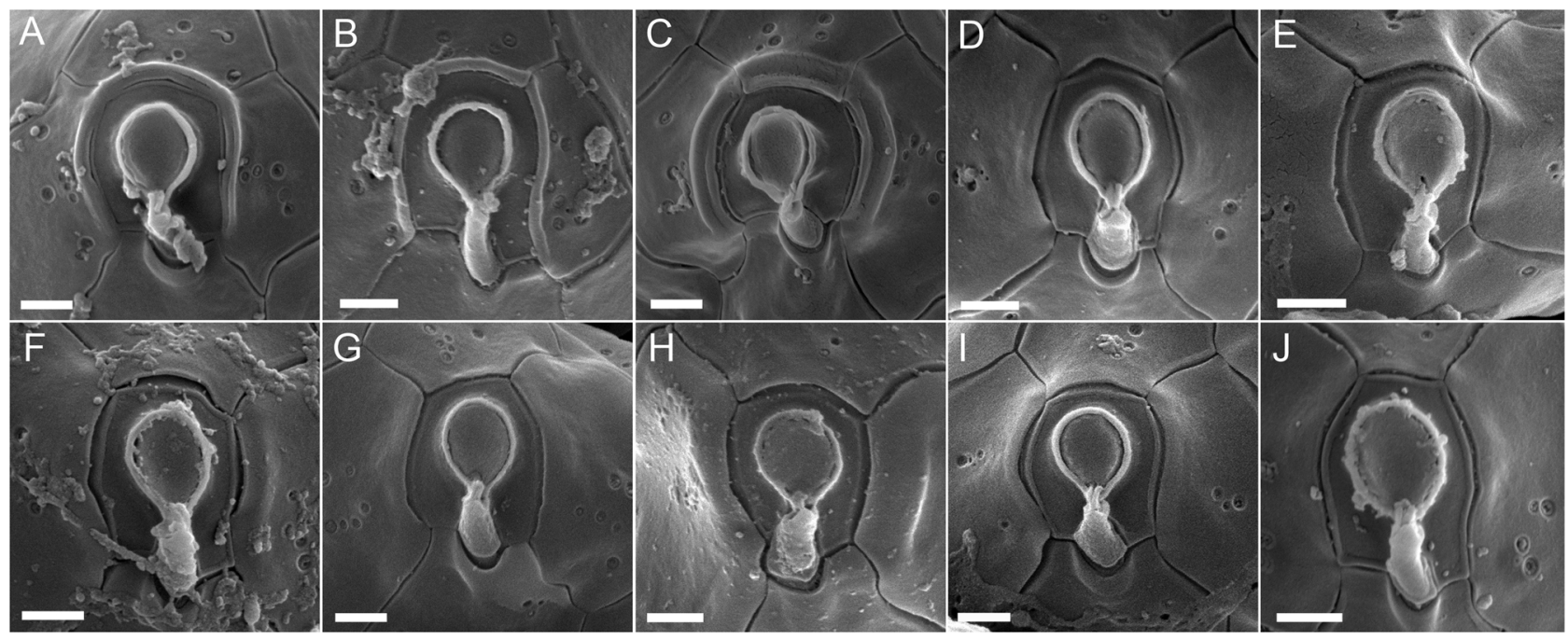

Fig. 13. Comparative detailed view of the apical pore complex. (A) Az. spinosum strain 3D9, type material of the species. (B) Az. spinosum N-04-01. (C) Az. spinosum N-04-02. (D) Az. spinosum N-04-04. (E) Az. spinosum N-05-01. (F) Az. spinosum N-05-02. (G) Az. spinosum N-14-02. (H) Az. spinosum N-16-01. (I) Az. spinosum N-16-02. (J) Az. spinosum N-39-02. Scale bars $=0.5 \mu \mathrm{m}$. 


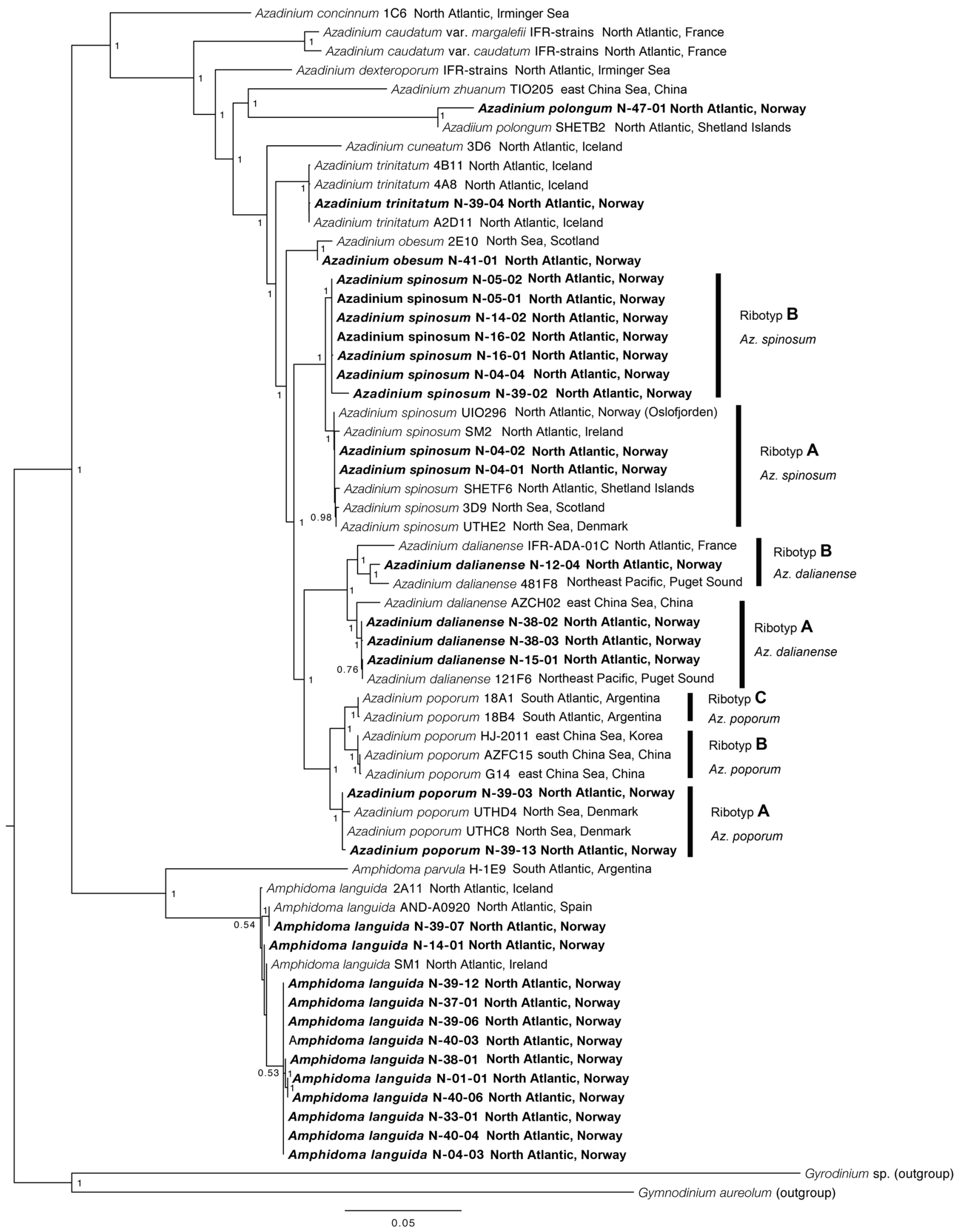

Fig. 14. Phylogenetic tree based on concatenated ribosomal DNA regions (SSU, ITS, 5.8S, ITS2, partial LSU) of members of Amphidomataceae (Suppl. Tabs S6, S7) using maximum likelihood (PhyML). Bootstrap values $>0.5$ are marked at the basal nodes. Gyrodinium sp. and Gymnodinium aureolum were used as outgroups. The alignment is available at https://figshare.com/s/ed5ba63189f39f0ce63d. 
A

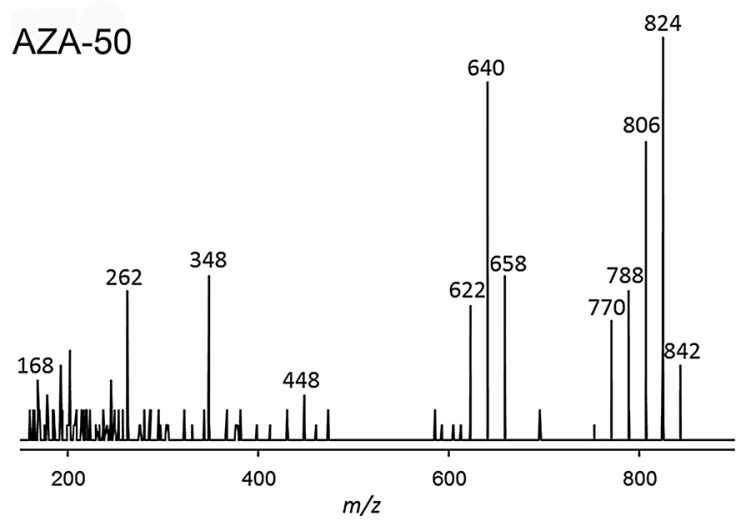

$B$

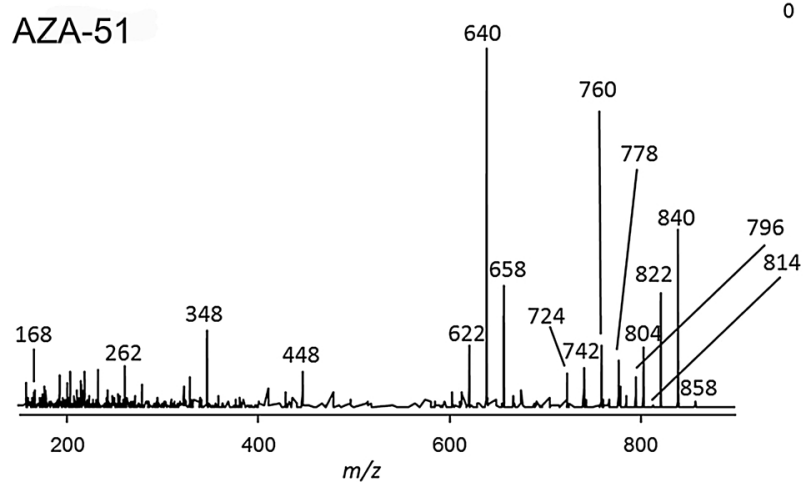

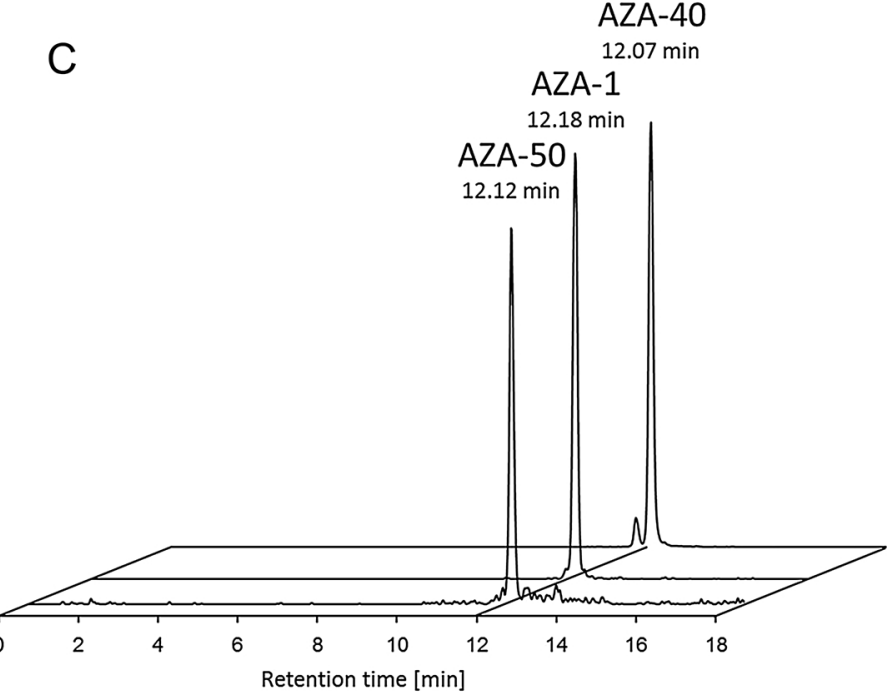

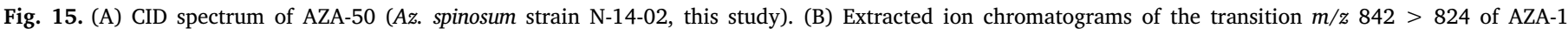

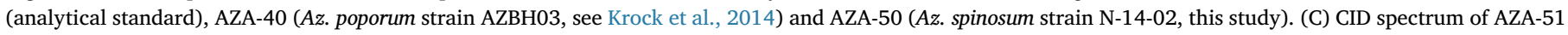
(Az. spinosum strain $\mathrm{N}-14-02$, this study).

molecular response of AZA-phosphates under ESI conditions and analytical standards of AZA-phosphates are not available, a quantification of AZA-phosphates is not possible. In addition, trace levels of the respective AZA methyl esters were recorded for some of the parent AZA. The abundance of AZA methyl esters did not exceed $10 \%$ of the respective unesterified AZA.

For the two yet unreported AZA of Az. spinosum, AZA-50 had a pseudo molecular ion $[\mathrm{M}+\mathrm{H}]^{+}$of $m / z$ 842. This mass was identical with the $[\mathrm{M}+\mathrm{H}]^{+}$ion of AZA-1, but its collision induced dissociation (CID) spectrum was clearly distinct from AZA-1, the type B, C and D fragment clusters $(m / z 672,462$, and 362) were 14 Da downshifted (Fig. 15A) indicating a missing methyl group in these fragments in comparison to AZA-1. The type E fragment $(\mathrm{m} / \mathrm{z} 262)$ was shared among AZA-1 and AZA-50. Given an only minor difference in the chemical structure of both compounds, their chromatographic behaviour was very similar and accordingly both compounds showed almost identical retention times of $12.18 \mathrm{~min}$ (AZA-1) and $12.12 \mathrm{~min}$ (AZA-50) (Fig. 15B).

The second AZA, AZA-51, had the $[\mathrm{M}+\mathrm{H}]^{+}$ion mass of $m / z 858$ and otherwise a very similar CID spectrum as AZA-50. The only two differences consisted in the $16 \mathrm{Da}$ higher pseudo molecular mass and a more complex type A fragment cluster in comparison to AZA-50 (Fig. 15C).

In all three Az. poporum strains only AZA-37 was detected as major compound (Table 2) (1.6-19.6 $\mathrm{fg}^{\text {cell }}{ }^{-1}$, Suppl. Tab. S2). Here, again, the respective AZA-37-phopshate was also present in minor amounts ranging from 0.5 to $5 \%$ of AZA-37 peak areas. For LOD of AZAs other than AZA-37 and AZA-37-P in Az. poporum see Suppl. Tab. S4.

Most of the Am. languida strains had identical AZA profiles consisting of AZA-38 and AZA-39 (Table 2), both in the same order of magnitude and with quite variable cell quotas ranging from 0.8 to $24.9 \mathrm{fg}$ cell $^{-1}$ (Suppl. Tab. S0). For three of the strains no AZA-38 could unambiguously be detected (Table 2). One of those strains (N-40-03) predominantly produced AZA-39 and an isobaric $(\mathrm{m} / \mathrm{z} 830)$, unreported AZA here named AZA-52 at a quota of about 1-6 $\mathrm{fg} \mathrm{cell}^{-1}$ (Suppl. Tab. S3). The other two strains lacking AZA-38 (N-39-07 and N-40-06) produced AZA-39 and another AZA isobaric with AZA-38 and AZA-52 $(\mathrm{m} / \mathrm{z}$ 830), here named AZA-53. The quotas of AZA-53 in these two

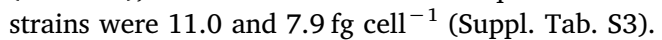

The two new AZA, AZA-52 and AZA-53 (Fig. 16, A, B), of the Am. languida strains showed almost identical CID spectra as AZA-38 (Fig. 16C), which despite their identical molecular masses and similar CID spectra easily could be differentiated by their chromatographic retention times, with AZA-52 eluting $0.5 \mathrm{~min}$ before AZA-38 and AZA530.9 min after AZA-38 (Fig. 16D).

\section{Discussion}

\subsection{Amphidomataceae in Norway: distribution, diversity, abundance}

Both light microscopy and real-time PCR assay revealed that Amphidomataceae are ubiquitous in summer plankton communities along the Norwegian coast and within large deep fjords such as Songnefjorden and Trondsheimsfjorden. The genus specific probe, which has been extensively tested for specificity (Smith et al., 2016), without exception was positive for all stations, and the specific probes for the two toxigenic species Azadinium poporum and Az. spinosum were negative for a few stations only. Notably, positive PCR signals for $A z$. spinosum but not for $A z$. poporum were obtained for the inner part of Sognefjorden and Trondheimsfjorden, indicating that Az. poporum 


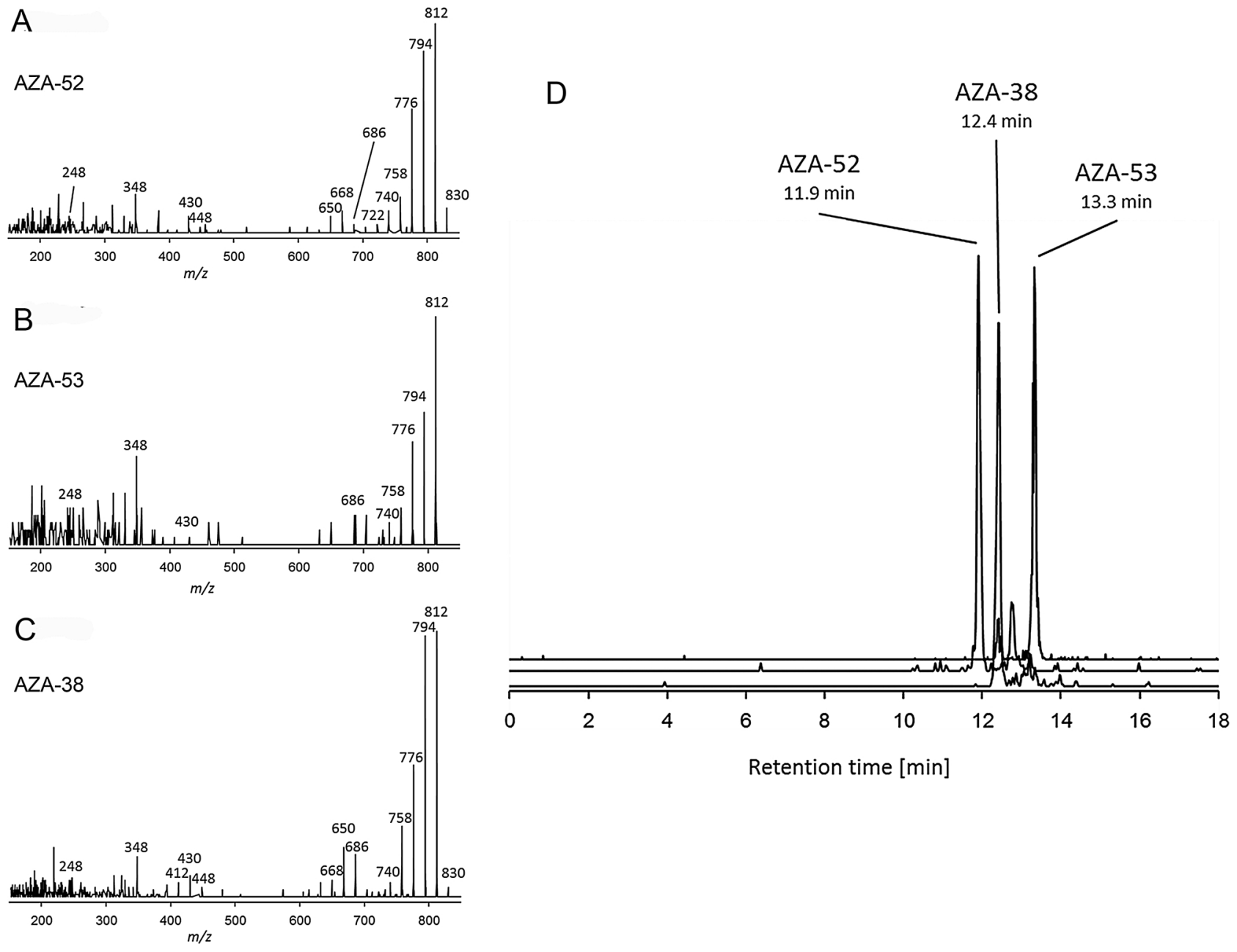

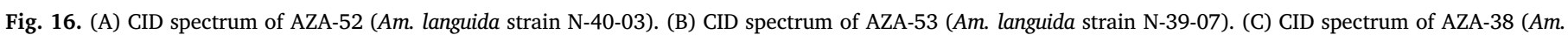
languida strain N-40-04). (D) Extracted ion chromatograms of the transition $m / z 830>812$ of AZA-38, AZA-52 and AZA-53.

might have a preference for high salinity open coastal waters.

Likewise supported by both microscopy and molecular detection is the conclusion that abundance of Amphidomataceae in July 2015 generally was low. Based on live cell observation of plankton samples, densities were roughly estimated to be not above and mostly well below a few hundreds of cells $\mathrm{L}^{-1}$, which is supported by the molecular assays. While the real-time PCR assays were not performed quantitatively, all samples that were positive using the Amphidomataceae assay indicated moderate to low cell abundance with increase in fluorescence detected only after 20 cycles (data not shown). A generally low abundance - at least for the toxigenic species - is also supported by the failure to detect AZA in plankton samples, where the limit of detection e.g. of AZA-1 would correspond to (assuming a cell quota of $10 \mathrm{fg}$

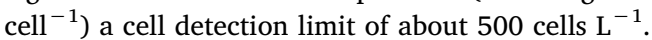

The present results further highlight a high and previously unknown species diversity of Amphidomataceae for the area. Previously, the published amphidomatacean species record from Norway are restricted to Az. caudatum (a non-AZA producing species) and to the description of a strain of $A z$. spinosum isolated in 2010 from Oslofjorden. Based on the new Norwegian strains it is now known that a number of other species, Az. spinosum, Az. obesum, Az. poporum, Az. dalianense, Az. trinitatum, Az. polongum, and Amphidoma languida are present in the area. Some species (Az. spinosum, Az. dalianense, Am. languida) were isolated from different stations along the coast, whereas for others (e.g. Az. polongum, $A z$ trinitatum, $A z$. obesum) only single strains from more northern stations were obtained. Because of the limited number of strains, however, conclusion about species-specific distribution pattern and potential distribution boundaries for amphidomatacean species, other that the two species ( $A z$. spinosum and $A z$. poporum) captured by the molecular probes, are not possible.

The new Norwegian strain of $A z$. obesum is a first confirmation of this species for the North Atlantic since the species description based on a strain from the North Sea off Scotland (Tillmann et al., 2010). The species $A z$. trinitatum was up to now only recorded from Iceland, so the new record by the Norwegian strain shows that the species also occurs further south. The species Az. polongum was described based on a strain from the Shetland Islands (Tillmann et al., 2012b), and a second record of $A$ z. polongum comes from a bloom in Peru (Tillmann et al., 2017b). Different to the Peruvian Az. polongum population, the Norwegian strain conforms with the type strain from the Shetlands by a consistent contact between plates 1' and 1a. Different to both the type culture and the Peruvian field population all cells of $A z$. polongum strain N-47-01 lack the antapical spine. Sequence comparison revealed that the type strain ShetB2 and the new Norwegian strain N-47-01 differed in 9 positions in the ITS and 9 positions in the LSU. Future studies and more strains of $A z$. polongum are needed to finally evaluate if such a significant genetic differentiation consistently correspond with morphological differences such as spine formation. Little is known how spine formation is affected by culture conditions and presence/absence of an antapical spine within clonal cultures is quite common (including the new Norwegian strains) for Az. dalianense (Luo et al., 2013; Kim et al., 2017).

The new Norwegian strains of $A z$. dalianense are the first strains from a northern area of the North Atlantic. Next to the type locality in 
China, the species was recorded from the French Atlantic coast and from the Northeast Pacific (Kim et al., 2017; Luo et al., 2018). All available strains of the species share the same morphology but exhibit significant sequence differences such that different ribotypes can be distinguished (Kim et al., 2017). Notably, in Norway strains of both $A z$. dalianense ribotypes co-occur, and such a sympatric occurrence of different ribotypes has previously been noted for Az. poporum in China (Gu et al., 2013) and the Greek Mediterranean area (Luo et al., 2018). Regardless of ribotype allocation, all Norwegian strains in culture had roughly the same proportion of cells with an antapical spine, which calls into question that spine frequency, as discussed by Kim et al. (2017), might be a consistent difference between $\mathrm{Az}$. dalianense ribotypes.

The three new strains of $A z$. poporum share the same morphology and sequence data and ribotype affiliation (Ribotype A) as the Az. poporum strains originating from the Danish West coast (Tillmann et al., 2011).

Based on the large number of strains obtained from different parts of the Norwegian coast Am. languida seems to be a somewhat widespread and relatively abundant species. Based on LSU sequence data there are also indications for the presence of different clades for this species, but statistical support was low. Generating ITS sequences for the Am. languida strains failed likely because there seem to be a high intragenomic ITS variability as evidenced for a clonal culture of Am. languida from Spain (Tillmann et al., 2017a).

One of the most important findings of the present study is that a genetic substructure within Az. spinosum is reported. This species is assumed to be the most important European cause of AZA poisoning (Salas et al., 2011), and previous strains from Scotland, Ireland, and the Shetland Islands all share almost identical sequence data and AZA toxin profile consisting of AZA-1, -2, and -33 (Tillmann et al., 2012b; Kilcoyne et al., 2014). With the new Norwegian strains it is obvious that within Az. spinosum there are now two well resolved ribotypes. As will be discussed in more detail below, strains of the different ribotypes also differ in their toxin profile, with strains of Ribotype A producing AZA-1, AZA-2 and AZA-33, whereas strains of Ribotype B produce mainly AZA11 and the new AZA-51. A close and detailed SEM view indicate that there are minor morphological differences among ribotypes as well (Fig. 13): strains of Ribotype A consistently have a distinct rim running around the pore plate, whereas for species of Ribotype B this structure was absent or at most rudimentary adumbrated. These sequence and morphological differences, however, are currently not sufficient to consider further taxonomic differentiation of the strains. It is important to note that in Norway both ribotypes of $A z$. spinosum obviously cooccur: strains of $A z$. spinosum Ribotype A (e.g. N-04-01) and B (e.g. N04-04) were obtained even from the same station.

Nevertheless, the new findings for Az. spinosum have an important implication. Sequence differences between both ribotypes comprise areas of the LSU which currently are used of the species specific qPCR probes designed for Az. spinosum (Toebe et al., 2013). Sequence comparison of the spinosum-probe and sequences of all Ribotype B Az. spinosum revealed one G-A- mismatch from the 5'end, and two mismatches with the reverse primer from the $5^{\prime}$ end. This in silico comparison indicates that Ribotype B strains may amplify but surely with a lower efficiency, which was confirmed by first tests using the real-time PCR assay and extracted DNA from Ribotype B strains (Smith, Paterson, Tillmann, unpublished). This of course has major implications for monitoring programs currently using the spinosum-probe, which in a next step needs to be re-designed in order to fully capture all strains of this important toxigenic species.

\subsection{New toxins}

Another important finding of the present study is that Norwegian strains produce some previously unreported AZA for Norway (AZA-11, AZA-37, AZA-38, AZA-39) and also four novel (AZA-50, -51, -52, -53)
AZA compounds, whose structural properties will be briefly discussed: AZA-50: The fragmentation pattern of AZA-50 with type B, C and D fragment clusters $(m / z 658,448$, and 348) 14 Da smaller than those of AZA-1 $(m / z 672,462$, and 362) and the identical type E fragment of $m /$ $z 262$ is consistent with a shift of the 23-methyl group of AZA-1 to the 8position in AZA-50 resulting in 23-desmethyl-AZA-2. This, however, is only the most plausible structural proposal derived from mass spectrometric data only and other, even though less probable, structural variants are theoretically possible, which highlights the need for nuclear magnetic resonance (NMR) spectroscopy for complete and unambiguous structural elucidation. The detection and presence of AZA50 deserves special attention as it has the identical mass as AZA-1 and in addition both AZA almost co-elute (12.12 min vs. $12.18 \mathrm{~min}$ ) and are not separable by standard chromatographic methods (Fig. 15B). The chromatographic and mass spectral similarity of AZA-1 and AZA-50 poses a high risk of misidentification of both compounds. This is particularly important in food safety control, which regulates AZA-1 but to date not the new isomer AZA-50. In fact, AZA-50 is the second structural isomer of AZA-1. Recently AZA-40 has been described in Az. poporum from the Northwest Pacific (compound 2 in Krock et al., 2014), which shares the identical mass and almost the same chromatographic retention time with AZA-1 and AZA-50 (Fig. 15B).

AZA-51: The AZA-51 with its 16 Da higher pseudo molecular mass than AZA-50 seems to be its hydroxylated form. This is supported by identical type B, C, D and E fragments of both compounds, which is evidence of their structural similarity. Furthermore, the pseudo molecular ion cluster in addition to several water losses shows the loss of $\mathrm{CO}_{2}$ and several water losses which are only observed in 3-hydroxylated AZA (Krock et al., 2015), which leads to the conclusion that AZA-51 is 3-hydroxy-AZA-50 (or 23-desmethyl-3-hydroxy-AZA-2). Like in the case of AZA-50 final structural elucidation of AZA-51 by NMR spectroscopy still remains to be determined.

AZA-52 and AZA-53: The CID spectra of AZA-52 and AZA-53 from Am. languida (Fig. 16A, B) are almost identical with the CID spectrum of AZA-38 (Fig. 16C) suggesting very similar structural features of all three compounds. Even though the structure of AZA-38 to date has not been unambiguously elucidated by NMR, there is compelling mass spectral evidence that AZA-38 (compound 3 in Krock et al., 2012) is a variant of AZA-37 (compound 2 in Krock et al., 2012, revised structure in Krock et al., 2015) without the 3-hydroxylation resulting in 7,8-dihydro-39-demethyl-AZA-1. The very high similarity of the CID spectra of AZA-38, -52 and -53 displaying the same fragments leads to the conclusion that AZA-52 and AZA-53 are isomers of AZA-38. This is consistent with the fact that all three compounds are produced by $A m$. languida and thus similar biosynthetic pathways being involved. In any case, without NMR experiments the exact chemical structures of AZA52 and AZA-53 cannot be determined and it is even impossible to decide, if AZA-52 and AZA-53 are stereo or structural isomers of AZA-38. Despite the structural similarities, the chromatographic behaviour of these three AZA differs markedly by retention of more than one minute with the elution order of AZA-52 (11.9 min) followed by AZA-38 (12.4. $\mathrm{min}$ ) and AZA-53 (13.3 min) (Fig. 16D). Due to their very distinct retention times AZA-38, -52 and -53 can easily be differentiated by LC-MS/MS despite their identical mass transitions and almost identical CID spectra.

\subsection{Toxin profiles}

Analysis of previously described strains of species regarded as nontoxigenic from other geographic locations, such as Az. obesum from the Scottish East coast (Tillmann et al., 2010) and from Puget Sound (Kim et al., 2017), Az. polongum from Shetland (Tillmann et al., 2012b) or from a bloom population from Peru (Tillmann et al., 2017b), $A z . d a-$ lianense from the Yellow Sea (China) (Luo et al., 2013), from France (Luo et al., 2017) and from Washington State (Kim et al., 2017), and from $A z$. trinitatum from the Irminger Sea between Greenland and 
Iceland (Tillmann et al., 2014a) confirmed the absence of AZA also in strains of these species from Norwegian coastal waters. Even though there are still relatively few strains of these Azadinium species available, the results for the new Norwegian strains add to the suggestion that non-toxigenicity is a stable trait of these four species.

The species $A z$. spinosum has been reported from various locations of the Northeast Atlantic (Tillmann et al., 2009; Salas et al., 2011; Krock et al., 2013) and the Mexican Pacific (Hernández-Becerril et al., 2012). Whereas no information for toxin profiles are available from Mexico, all other previous strains of $A z$. spinosum show the same AZA profiles consisting mainly of AZA-1, AZA-2 and AZA-33 (Tillmann et al., 2009; Kilcoyne et al., 2014) with some variations in the relative abundances of these three AZA. With the availability of the new Norwegian Az. spinosum strains and the recognition of genetic differentiation within the species it becomes clear that different ribotypes have different toxin profiles. Two of the new Norwegian Az. spinosum strains from southern area (N-04-01 and N-04-02) are of Ribotype A and share the same AZA profile (AZA-1, -2, -33) with the previous Ribotype A strains, but the other strains from different areas (station 4, 5, 14, 16, 39, see Fig. 1) had completely different toxin profiles consisting of AZA-51 and (in 5 strains) AZA-11, and one of these strains (N-14-02) produced also AZA50.

Azaspiracid-11 was originally detected in Irish mussels (James et al., 2003) and is thus regarded as a shellfish metabolite of AZA-2 formed by enzymatic hydroxylation. Recent studies proved that AZA-11 also is de novo synthesized by Az. poporum in the Pacific area (Krock et al., 2014; Tillmann et al., 2017c) and in the Mediterranean as well (Luo et al., 2018). The present results now show that AZA-11 can also be produced by $A z$. spinosum, albeit at rather low amounts $(<1 \mathrm{fg}$ cell $^{-1}$ ). So AZA-11 and AZA-2 are both found in (at least some strains of) two different Azadinium species, whereas AZA-1 up to now is only known from $A z$. spinosum. Interestingly, AZA-2 was also found in a Spanish strain of Amphidoma languida (Tillmann et al., 2017a).While all this could be interesting from a biosynthetic and phylogenetic perspective, more data are needed for a broader interpretation of these findings.

For $A z$. poporum, a larger number of strains from various areas revealed a high variability in AZA production profile on a global scale (Krock et al., 2012, 2014; Krock et al., 2015; Luo et al., 2016; Smith et al., 2016; Tillmann et al., 2016; Kim et al., 2017; Luo et al., 2017; Tillmann et al., 2017c). On a more local scale, different strains of $\mathrm{Az}$. poporum from the same area of the China Sea also revealed toxin profile variability (Krock et al., 2014). From the North Atlantic, the three available strains from Denmark produce only AZA-37 (Krock et al., 2013), and this is confirmed by AZA-37 production by the three Norwegian Az. poporum strains reported in this study.

Shortly after the taxonomic description of Am. languida (Tillmann et al., 2012a), the type culture from the Irish West Coast was discovered to produce two novel AZA (AZA-38 and AZA-39) (Krock et al., 2012), The same toxin profile was also found in Am. languida isolated from the Irminger Sea (Tillmann et al., 2015) whereas a recently isolated strain of Am. languida from the Spanish Atlantic produced a completely different profile consisting of AZA-2 and -43 (Tillmann et al., 2017a). The majority (nine of twelve) of the new Am. languida strains from Norway displayed the same toxin profile as the Irish and Irminger Sea strains consisting of AZA-38 and AZA-39. Whereas all twelve isolates consistently produced AZA-39, three isolates produced AZA-52 or AZA-53 instead of AZA-38. Azaspiracid-38, AZA-52 and AZA-53 must be structurally closely related as all three AZA have almost identical CID spectra (Fig. 16A-C), but clearly distinct retention times (Fig. 16 D). An obvious explanation might be that these differences are a simple extraction artefact, i.e. modifications of the compound during the extraction procedure, or that the observed retention time shifts are caused by chromatographic problems. The first scenario can be ruled out by the fact that all samples were treated the same way. If extraction artefacts occurred, they would be expected in all samples and the finding of AZA-
52 and AZA-53 in only few strains argues against a posterior modification. Chromatographic problems also can be ruled out by the fact that all strains contained AZA-39, which in all cases eluted at the same retention time. Taking all this information together, it must be concluded that AZA-52 and AZA-53 were ab initio present in the respective strains. This conclusion leads to the assumption that AZA-52 and AZA53 could be epimers of AZA-38. In fact, epimerization of AZA already has been observed by heat treatment of mussels contaminated with AZA (Kilcoyne et al., 2015), but epimerizations are equilibrium processes that result in several epimers so that post-biosynthetic epimerization does not seem likely, if only one epimer is present. Furthermore, biosynthetic processes have a high degree of chiral specificity and it is absolutely unexpected that one species would produce different epimers in different strains, especially if only a single epimer of co-occurring AZA-39 is observed.

Azaspiracids have been known for almost twenty years, but only very recently the presence of AZA phosphates as minor components with a $80 \mathrm{Da}$ higher molecular mass as the respective free AZA forms was documented (Tillmann et al., 2016, 2017c). Phosphates of AZA-38 and AZA-39 also have now been detected in the Norwegian Am. languida strains. A lack of AZA phosphate in some of the Am. languida strains may just be a sensitivity problem depending on the available biomass (see suppl. Tab S1). For all other AZA reported here like AZA11 and AZA-51 of Az. spinosum and AZA-37 of Az. poporum, the respective phosphates are also present, a clear indication that the presence of AZA phosphates is a common trait in AZA producing Amphidomataceae.

In addition to AZA phosphates, also AZA methyl esters (Me-AZA) were detected in some of the AZA-producing strains. In fact, Me-AZA were detected from the very beginning of the discovery of AZA-producing species (AZA-X in Krock et al., 2009; Tillmann et al., 2009) and were later confirmed as Me-AZA by chemical methylation of AZA (Krock et al., 2012). At that time methanol was used as an extraction solvent for AZA and after reassessment of archived AZA-containing samples it could be confirmed that methylation of AZA occurred spontaneously in frozen archived samples as a result of esterification of AZA by the extraction solvent methanol, however, at a very slow rate. As methylation of AZA by storage in methanol became evident, AZA samples, if not directly extracted with aprotic acetone, were dried and taken up in acetone for measurement and storage. Despite of the avoidance of protic extraction solvents that may undergo chemical reactions with AZA, Me-AZA are eventually found in lower amounts in AZA-containing extracts of Amphidomataceae indicating that Me-AZA are not only extraction artefacts, if methanol is used as extraction solvent, but also may be part of AZA profiles of the respective AZA-producing organisms.

\section{Conclusion}

Even when abundance of Amphidomataceae in Summer 2015 was generally low and AZA toxins were not detected in plankton samples, the wide distribution and diversity in amphidomatacean species all along the Norwegian coast underlines the conclusion that it is important that amphidomatacean species as producers of AZA are taken into account in future studies and design of monitoring programs. The report of new AZA produced by local strains of $A z$. spinosum now allows to up-date the chemical methods to include these compounds in future monitoring analysis. Molecular probes for routine detection and quantification are currently available for $A z$. poporum and Az. spinosum, however, the new strains of Norwegian $A z$. spinosum also revealed that the existing probe needs to be re-designed in order to fully capture all strains of the species.

\section{Acknowledgements}

We thank Wolfgang Drebing and Annegret Müller (AWI, 
Bremerhaven, Germany) for technical support. Captain Voß and the entire FS Heincke crew provided assistance and logistical support for the collection of field material used in this study. Financial support was provided by the PACES research program of the Alfred Wegener Institute as part of the Helmholz Foundation initiative in Earth and Environment, and by the German Ministry for Education and Research (project RIPAZA, 03F0763A).[CG]

\section{Appendix A. Supplementary data}

Supplementary material related to this article can be found, in the online version, at doi:https://doi.org/10.1016/j.hal.2018.08.011.

\section{References}

Aasen, J., Samdahl, I.A., Miles, C.O., Dahl, E., Briggs, L.R., Aune, T., 2005. Yessotoxins in Norwegian blue mussels (Mytilus edulis): uptake from Protoceratium reticulatum, metabolism and peduration. Toxicon 45, 265-272.

Aasen, J., Torgersen, T., Dahl, E., Naustvoll, L.J., Aune, T., 2006. Confirmation of azas piracids in mussels in Norwegian coastal areas, and full profile at one location. Henshilwood, K., Deegan, B., McMahon, T., Cusack, C., Keaveney, S., Silke, J., O'Cinneide, M., Lyonns, D., Hess, P. (Eds.), Proceedings of the 5th International Conference on Molluscan Shellfish Safety, Galway, Ireland, June 14th -18th, 2004 $162-169$.

Álvarez, G., Uribe, E., Ávalos, P., Mariño, C., Blanco, J., 2010. First identification of azaspiracid and spirolides in Mesodesma donacium and Mulinia edulis from Northern Chile. Toxicon 55, 638-641.

Arar, E.J., Collins, G.B., 1997. Method 445.0: In Vitro Determination of Chlorophyll a and Pheophytin a in Marine and Freshwater Algae by Fluorescence. U.S. Environ. Prot. Agency, Off. of Res. and Dev., Natl. Exposure Res. Lab., Cincinatti, Ohio 26 pp.

Aune, T., Strand, Ö., Aase, B., Weidemann, J., Dahl, E., Hovgaard, P., 1996. The Sognefjord in Norway, a possible location for musselfarming? In: Yasumoto, T., Oshima, Y., Fukuyo, Y. (Eds.), Harmful and Toxic Algal Blooms. Intergovernmental Oceanographic Commision of UNSECO, Paris, pp. 73-76.

Blanco, J., Arevalo, F., Morono, A., Correa, J., Muniz, S., Marino, C., Martin, H., 2017. Presence of azaspiracids in bivalve molluscs from northern Spain. Toxicon 137, 135-143.

Dahl, E., Johannessen, T., 2001. Relationship between occurrence of Dinophysis species (Dinophyceae) and shellfish toxicity. Phycologia 40, 223-227.

Dahl, E., Tangen, K., 1993. 25 years experience with Gyrodinium aureolum in Norwegian waters. In: Smayda, T.J., Shimizu, Y. (Eds.), Toxic Phytoplankton Bloom in the Sea. Elsevier Science Publisher, Amsterdam, pp. 15-21.

Dahl, E., Tangen, K., 1999. The life with harmful algae in Norway - management. ICES 1999 Annual Science Conference CM 1999/N: 05. pp. 1-7.

Dundas, I., Johannessen, O.M., Berge, G., Heimdahl, B., 1989. Toxic algae blooms in Scandinavian waters, May-June 1988. Oceanography 2, 9-14.

Edvardsen, B., Eikrem, W., Shalchian-Tabrizi, K., Riisberg, I., Johnsen, G., Naustvoll, L., Throndsen, J., 2007. Verrucophora farcimen gen. et sp. nov. (Dictyochophyceae, Heteroconta)- a bloom-forming ichtyotoxic flagellate from the Skagerrak, Norway. J. Phycol. 43, 1054-1070.

Gu, H., Luo, Z., Krock, B., Witt, M., Tillmann, U., 2013. Morphology, phylogeny and azaspiracid profile of Azadinium poporum (Dinophyceae) from the China Sea. Harm. Algae 21-22, 64-75.

Guindon, S., Dufayard, J.F., Lefort, V., Anisimova, M., Hordijk, W., Gascuel, O., 2010. New algorithms and methods to estimate maximum-likelihood phylogenies: assessing the performance of PhyML 3.0. Syst. Biol. 59, 307-321.

Halldal, P., 1953. Phytoplankton investigations from Weather Ship M in the Norwegian Sea, 1948-49. Hvalrådets Skrifter 38, 1-91.

Hernández-Becerril, D.U., Barón-Campis, S.A., Escobar-Morales, S., 2012. A new record of Azadinium spinosum (Dinoflagellata) from the tropical Mexican Pacific. Rev. Biol. Mar. Oceanogr. 47, 553-557.

Hess, P., McCarron, P., Krock, B., Kilcoyne, J., Miles, C.O., 2014. Azaspiracids: chemistry, biosynthesis, metabolism, and detection. In: Botana, L.M. (Ed.), Seafood and Freshwater Toxins. CRC Press, Boca Raton, USA, pp. 799-821.

Jakobsen, R., Hansen, P.J., Daugbjerg, N., Andersen, N.G., 2012. The fish-killing dic tyochophyte Pseudochattonella farcimen: adaptations leading to bloom formation during early spring in Scandinavian waters. Harm. Algae 18, 84-95.

James, K.J., Furey, A., Lehane, M., Ramstad, H., Aune, T., Hovgaard, P., Morris, P., Higman, W., Satake, M., Yasumoto, T., 2002. First evidence of an extensive northern European distribution of azaspiracid poisoning (AZP) toxins in shellfish. Toxicon 40, 909-915.

James, E.J., Sierra, M.D., Lehane, M., Brana Magdalena, A., Furey, A., 2003. Detection of five new hydroxyl analogues of azaspiracids in shellfish using multiple tandem mass spectrometry. Toxicon 41, 277-283.

Johnsen, T.M., Lein, T.E., 1989. Prymnesium parvum Carter (Prymnesiophyceae) in association with macroalgae in Ryfylke, southwestern Norway. Sarsia 74, 277-281.

Katoh, K., Rozewicki, J., Yamada, K.D., 2017. MAFFT online service: multiple sequence alignment, interactive sequence choice and visualization. Brief. Bioinf. https://doi. org $/ 10.1093 / \mathrm{bib} / \mathrm{bbx} 108$

Keller, M.D., Selvin, R.C., Claus, W., Guillard, R.R.L., 1987. Media for the culture of oceanic ultraphytoplankton. J. Phycol. 23, 633-638.
Kilcoyne, J., Nulty, C., Jauffrais, T., McCarron, P., Herve, F., Foley, B., Rise, F., Crain, S., Wilkins, A.L., Twiner, M.J., Hess, P., Miles, C.O., 2014. Isolation, structure elucidation, relative LC-MS response, and in vitro toxicity of azaspiracids from the dinoflagellate Azadinium spinosum. J. Nat. Prod. 77, 2465-2474.

Kilcoyne, J., McCarron, P., Hess, P., Miles, C.O., 2015. Effects of heating on proportions of azaspiracids 1-10 in mussels (Mytilus edulis) and identification of carboxylated precursors for azaspiracids 5, 10, 13, and 15. J. Agric. Food Chem. 63, 10980-10987.

Kim, J.W., Tillmann, U., Adams, N.G., Krock, B., Stutts, W.L., Deeds, J.R., Han, M.S., Trainer, V.L., 2017. Identification of Azadinium species and a new azaspiracid from Azadinium poporum in Puget Sound, Washington State, USA. Harm. Algae 68, $152-167$.

Krock, B., Tillmann, U., John, U., Cembella, A.D., 2009. Characterization of azaspiracids in plankton size-fractions and isolation of an azaspiracid-producing dinoflagellate from the North Sea. Harm. Algae 8, 254-263.

Krock, B., Tillmann, U., Voß, D., Koch, B.P., Salas, R., Witt, M., Potvin, E., Jeong, H.J., 2012. New azaspiracids in Amphidomataceae (Dinophyceae): proposed structures. Toxicon 60, 830-839.

Krock, B., Tillmann, U., Alpermann, T.J., Voß, D., Zielinski, O., Cembella, A., 2013. Phycotoxin composition and distribution in plankton fractions from the German Bight and Western Danish Coast. J. Plankton Res. 35, 1093-1108.

Krock, B., Tillmann, U., Witt, M., Gu, H., 2014. Azaspiracid variability of Azadinium poporum (Dinophyceae) from the China Sea. Harm. Algae 36, 22-28.

Krock, B., Tillmann, U., Potvin, E., Jeong, H.J., Drebing, W., Kilcoyne, J., Al-Jorani, A., Twiner, M.J., Göthel, Q., Köck, M., 2015. Structure elucidation and in vitro toxicity of new azaspiracids isolated from the marine dinoflagellate Azadinium poporum. Mar. Drugs 13, 6687-6702.

Larsen, A., Eikrem, W., Paasche, E., 1993. Growth and toxicity in Prymnesium patelliferum (Prymnesiophyceae) isolated from Norwegian waters. Can. J. Bot. 71, 1357-1362.

Lee, J.S., Tangen, K., Dahl, E., Hovgaard, P., Yasumoto, T., 1988. Diarrhetic shellfish toxins in Norwegian mussels. Nippon Suisan Gakkaishi 54, 1953-1957.

Luo, Z., Gu, H., Krock, B., Tillmann, U., 2013. Azadinium dalianense, a new dinoflagellate from the Yellow Sea, China. Phycologia 52, 625-636.

Luo, Z., Krock, B., Mertens, K.N., Price, A.M., Turner, R.E., Rabalais, N.N., Gu, H., 2016. Morphology, molecular phylogeny and azaspiracid profile of Azadinium poporum (Dinophyceae) from the Gulf of Mexico. Harm. Algae 55, 56-65.

Luo, Z., Krock, B., Mertens, K., Nézan, E., Chomerat, N., Bilien, G., Tillmann, U., Gu, H., 2017. Adding new pieces to the Azadinium (Dinophyceae) diversity and biogeography puzzle: non-toxigenic Azadinium zhuanum sp. nov. from China, toxigenic A. poporum from the Mediterranean, and a non-toxigenic A. dalianense from the French Atlantic. Harm. Algae 66, 65-78.

Luo, Z., Krock, B., Giannakourou, A., Venetsanopoulou, A., Pagou, K., Tillmann, U., Gu, H., 2018. Sympatric occurrence of two Azadinium poporum ribotypes in the Eastern Mediterranean Sea. Harm. Algae 78, 75-85.

Massucatto, A., Siqueira Pilotto, A.L., Schramm, M.A., 2014. Investigação da presença de Azaspirácidos em recursos pesqueiros do Canal do Linguado. ISSN 2357-836X. SEPEI. Instituto Federal, Santa Catarina.

McMahon, T., Silke, J., 1996. West coast of Ireland; winter toxicity of unknown aetiology in mussels. Harm. Algae News 14, 2.

Naustvoll, L., Gustad, E., Dahl, E., 2012. Monitoring of Dinophysis species and diarrhetic shellfish toxins in Flodevigen Bay, Norway: inter-annual variability over a 25-year time-series. Food Addit. Contam.: Part A 29, 1605-1615.

Orr, R., Murray, S.A., Stüken, A., Rhodes, L., Jakobsen, K.S., 2012. When naked became armored: an eight-gene phylogeny reveals monophyletic origin of theca in dinoflagellates. PLoS One 7, e50004.

Preston-Thomas, H., 1990. The international temperature scale of 1990 (ITS-90). Metrologia 27, 3-10.

Rossi, R., Dell'Aversano, C., Krock, B., Ciminiello, P., Percopo, I., Tillmann, U., Soprano, V., Zingone, A., 2017. Mediterranean Azadinium dexteroporum (Dinophyceae) produces AZA-35 and six novel azaspiracids: a structural study by a multi-platform mass spectrometry approach. Anal. Bioanal. Chem. 409, 1121-1134.

Rundberget, T., Gustad, E., Samdal, I.A., Sandvik, M., Miles, C.O., 2009. A convenient and cost-effective method for monitoring marine algal toxins with passive samplers. Toxicon 53, 543-550.

Salas, R., Tillmann, U., John, U., Kilcoyne, J., Burson, A., Cantwell, C., Hess, P., Jauffrais, T., Silke, J., 2011. The role of Azadinium spinosum (Dinophyceae) in the production of Azaspiracid Shellfish Poisoning in mussels. Harm. Algae 10, 774-783.

Satake, M., Ofuji, K., James, K., Furey, A., Yasumoto, T., 1998. New toxic events caused by Irish mussels. In: Reguera, B., Blanco, J., Fernandez, M.L., Wyatt, T. (Eds.), Harmful Algae. Xunta de Galicia and International Oceanographic Commission of UNESCO, Santiago de Compostela, pp. 468-469.

Smith, K.F., Rhodes, L., Harwood, D.T., Adamson, J., Moisan, C., Munday, R., Tillmann, U., 2016. Detection of Azadinium poporum in New Zealand: the use of molecular tools to assist with species isolations. J. Appl. Phycol. 28, 1125-1132.

Taleb, H., Vale, P., Amanhir, R., Benhadouch, A., Sagou, R., Chafik, A., 2006. First detection of azaspiracids in mussels in north west Africa. J. Shellfish Res. 25, 1067-1070.

Tangen, K., 1983. Shellfish poisoning and the occurence of potentially toxic dinoflagellates in Norwegian waters. Sarsia 68, 1-7.

Throndsen, J., Hasle, G.R., Tangen, K., 2007. Phytoplankton of Norwegian Coastal Waters. Almater Forlag AS, Oslo, pp. 343.

Tillmann, U., Akselman, R., 2016. Revisiting the 1991 algal bloom in shelf waters off Argentina: Azadinium luciferelloides sp. nov. (Amphidomataceae, Dinophyceae) as the causative species in a diverse community of other amphidomataceans. Phycol. Res. 64, 160-175.

Tillmann, U., Elbrächter, M., Krock, B., John, U., Cembella, A., 2009. Azadinium spinosum gen. et sp. nov. (Dinophyceae) identified as a primary producer of azaspiracid toxins. 
Eur. J. Phycol. 44, 63-79.

Tillmann, U., Elbrächter, M., John, U., Krock, B., Cembella, A., 2010. Azadinium obesum (Dinophyceae), a new nontoxic species in the genus that can produce azaspiracid toxins. Phycologia 49, 169-182.

Tillmann, U., Elbrächter, M., John, U., Krock, B., 2011. A new non-toxic species in the dinoflagellate genus Azadinium: A. poporumsp. nov. Eur. J. Phycol. 46, 74-87.

Tillmann, U., Salas, R., Gottschling, M., Krock, B., O’Driscoll, D., Elbrächter, M., 2012a. Amphidoma languida sp. nov. (Dinophyceae) reveals a close relationship between Amphidoma and Azadinium. Protist 163, 701-719.

Tillmann, U., Söhner, S., Nézan, E., Krock, B., 2012b. First record of Azadinium from the Shetland Islands including the description of A. polongum sp. nov. Harm. Algae 20, 142-155.

Tillmann, U., Gottschling, M., Nézan, E., Krock, B., Bilien, G., 2014a. Morphological and molecular characterization of three new Azadinium species (Amphidomataceae, Dinophyceae) from the Irminger Sea. Protist 165, 417-444.

Tillmann, U., Krock, B., Taylor, B., 2014b. Azadinium caudatum var. margalefii, a poorly known member of the toxigenic genus Azadinium (Dinophyceae). Mar. Biol. Res. 10, 941-956.

Tillmann, U., Gottschling, M., Nézan, E., Krock, B., 2015. First record of Azadinium dexteroporum and Amphidoma languida (Amphidomataceae, Dinophyceae) from the Irminger Sea off Iceland. Mar. Biodivers. Rec. 8, 1-11.

Tillmann, U., Borel, M., Barrera, F., Lara, R., Krock, B., Almandoz, G., Trefault, N., 2016. Azadinium poporum (Dinophyceae) from the South Atlantic off the Argentinean coast produce AZA-2. Harm. Algae 51, 40-55.

Tillmann, U., Jaen, D., Fernandez, L., Gottschling, M., Witt, M., Blanco, J., Krock, B., 2017a. Amphidoma languida (Amphidomataceae, Dinophyceae) with a novel azaspiracid toxin profile identified as the cause of molluscan contamination at the Atlantic coast of southern Spain. Harm. Algae 62, 113-126.

Tillmann, U., Sánchez Ramírez, S., Krock, B., Bernales Jiménez, A., 2017b. A bloom of Azadinium polongum in coastal waters off Peru. Rev. Biol. Mar. Oceanogr. 52, 591-610.
Tillmann, U., Trefault, N., Krock, B., Parada-Pozo, G., De la Iglesia, R., Vásquez, M., 2017c. Identification of Azadinium poporum (Dinophyceae) in the Southeast Pacific: morphology, molecular phylogeny, and azaspiracid profile characterization. J. Plankton Res. 39, 350-367.

Toebe, K., Joshi, A.R., Messtorff, P., Tillmann, U., Cembella, A., John, U., 2013. Molecular discrimination of taxa within the dinoflagellate genus Azadinium, the source of azaspiracid toxins. J. Plankton Res. 35, 225-230.

Torgersen, T., Bruun Bremmens, N., Rundberget, T., Aune, T., 2008. Structural confirmation and occurrence of azaspiracids in Scandinavian brown crabs (Cancer pagurus). Toxicon 51, 93-101.

Trainer, V.L., Moore, L., Bill, B.D., Adams, N.G., Harrington, N., Borchert, J., Da Silva, D.A.M., Eberhard, B.T.L., 2013. Diarrhetic shellfish toxins and other lipophilic toxins of human health concern in Washington State. Mar. Drugs 11, 1815-1835.

Tubaro, A., Dell’Ovo, V., Sosa, S., Florio, C., 2010. Yessotoxins: a toxicological overview. Toxicon 56, 163-172.

Turner, A.D., Goya, A.B., 2015. Occurrence and profiles of lipophilic toxins in shellfish harvested from Argentina. Toxicon 102, 32-42.

Twiner, M., Hess, P., Doucette, G.J., 2014. Azaspiracids: toxicology, pharmacology, and risk assessment. In: Botana, L.M. (Ed.), Seafood and Freshwater Toxins. CRC Press, Boca Raton, USA, pp. 823-855.

Underdahl, B., Ynestad, M., Aune, T., 1985. DSP intoxication in Norway and Sweden, autumn 1984 - spring 1985. In: Anderson, D.M., White, A.W., Baden, D.G. (Eds.), Toxic Dinoflagellates. Elsevier, New York, pp. 489-494.

Vale, P., Bire, R., Hess, P., 2008. Confirmation by LC-MS/MS of azaspiracids in shellfish from the Portuguese north-west coast. Toxicon 51, 1449-1456.

Yao, J., Tan, Z., Zhou, D., Guo, M., Xing, L., Yang, S., 2010. Determination of azaspiracid1 in shellfishes by liquid chromatography with tandem mass spectrometry. Chin. J Chromatogr. 28, 363-367.

Zielinski, O., Rohardt, G., 2016. Physical Oceanography During HEINCKE Cruise HE448. Alfred Wegener Inst., Helmholtz Cent. for Polar and Mar. Res., Bremerhaven, Germany. https://doi.org/10.1594/PANGAEA.859615. 